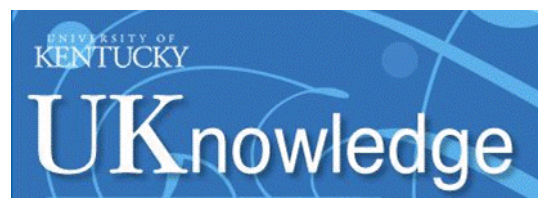

University of Kentucky

UKnowledge

\title{
Spatial and Temporal Variability in Seepage between a Contaminated Aquifer and Tributaries to the Ohio River
}

\author{
Alan E. Fryar \\ University of Kentucky, alan.fryar@uky.edu \\ David L. Brown \\ University of Kentucky \\ David B. Wenner \\ University of Kentucky \\ Todd C. Rasmussen \\ University of Kentucky \\ Eric J. Wallin \\ University of Kentucky
}

Follow this and additional works at: https://uknowledge.uky.edu/kwrri_reports

Part of the Geology Commons, and the Hydrology Commons

Right click to open a feedback form in a new tab to let us know how this document benefits you.

\section{Repository Citation}

Fryar, Alan E.; Brown, David L.; Wenner, David B.; Rasmussen, Todd C.; and Wallin, Eric J., "Spatial and Temporal Variability in Seepage between a Contaminated Aquifer and Tributaries to the Ohio River" (1998). KWRRI Research Reports. 8.

https://uknowledge.uky.edu/kwrri_reports/8

This Report is brought to you for free and open access by the Kentucky Water Resources Research Institute at UKnowledge. It has been accepted for inclusion in KWRRI Research Reports by an authorized administrator of UKnowledge. For more information, please contact UKnowledge@lsv.uky.edu. 


\title{
Spatial and Temporal Variability in seepage between a Contaminated Aquifer and Tributaries to the Ohio River
}

by

\author{
Alan E. Fryar \\ Principal Investigator \\ David L. Brown, David B. Wenner and Todd C. Rasmussen \\ Co-Principal Investigators \\ Eric J. Wallin \\ Graduate Assistant
}

\author{
Project Number:C-01 \\ Agreement No.: 1434-HQ-96-GR-026T2 \\ Period of Project: September 1996 to February 1998 \\ University of Kentucky \\ Kentucky Water Resources Research Institute \\ Lexington, KY 40506-0107
}

The work on which this report is based was supported in part by the Department of the Interior, Washington, D.C. as authorized by the Water Resources Research Act as amended in 1996 by P.L. 104-147 
Research Report No.

\title{
SPATIAL AND TEMPORAL VARIABILITY IN SEEPAGE BETWEEN A CONTAMINATED AQUIFER AND TRIBUTARIES TO THE OHIO RIVER
}

\author{
By \\ Alan E. Fryar \\ Principal Investigator \\ Eric J. Wallin \\ Graduate Assistant \\ David L. Brown, David B. Wenner, and Todd C. Rasmussen \\ Co-Principal Investigators
}

Project Number:

Agreement Number:

Period of Project: September 1996 to February 1998
Water Resources Research Institute
University of Kentucky
Lexington, $\mathrm{KY}$

The work upon which this report is based was supported in part by funds provided by the United States Department of the Interior, Washington, DC, as authorized by the Water Resources Research Act of P.L. 101-397. 


\begin{abstract}
Because interactions between ground water and tributaries may influence contaminant loading to rivers, we delineated seepage along Little Bayou and Bayou Creeks in McCracken County, Kentucky, during a two-year period. From the Paducah Gaseous Diffusion Plant, on the divide between the creeks, trichloroethene and technetium-99 plumes extend several km toward the Ohio River. Gaining conditions occur where the creeks are incised into coarse sediments in the river's flood plain. Such conditions were marked by upward hydraulic gradients within the bed; maximum specific discharge (q) $>0.24 \mathrm{~m} \mathrm{~d}^{-1}$; relatively narrow ranges of stream, piezometer, and bed temperatures; relatively cool bed and bank temperatures in summer and early autumn; detections of trace solutes in stream water; and observations of springs, boils, and seeps. Evidence of losing or no-net-discharge conditions included downward or lateral hydraulic gradients; minimal q values (indicative of stream-water flow through the bed); and relatively broad annual ranges of stream and piezometer temperatures. Mixing calculations using $\delta^{18} \mathrm{O}$ and $\mathrm{Cl}^{-}$ support inferences about gaining and losing reaches. Seepage rates and directions changed during dry periods in summer and early autumn and following Ohio River flooding in spring. Discharge of uncontaminated ground water dilutes contaminants in Little Bayou Creek.
\end{abstract}

Focus categories: GW, SW, TS

Keywords: Surface-groundwater relationships, streams, base flow, water quality, contaminant transport 


\section{ACKNOWLEDGMENTS}

The research described herein was supported in part by the Agreement-in-Principle between the U.S. Department of Energy and the Commonwealth of Kentucky through the Kentucky Water Resources Research Institute. The contents of this paper do not necessarily reflect the views and policies of the Departments of the Interior and Energy, nor does mention of trade names or commercial products constitute endorsement by the United States Government. We thank DOE, TVA, the Kentucky Department of Fish and Wildlife Resources, and Ronald Lamb for access to their properties. We are indebted to the University of Kentucky Federal Facilities Oversight Unit and Lockheed Martin Energy Systems, especially Jana White, for logistical support. David Butler, Mark Kulp, Danita LaSage, Jonathan McIntyre, Todd Mullins, Christofer Sweat, Matt Vick, and Jessica Wichtowski (who also aided in data processing) helped with field work. We appreciate the assistance of Bart Davidson and Richard Smath (Kentucky Geological Survey) and David Reynolds with surveying; Bill McClain with ${ }^{18} \mathrm{O}$ analyses; and Alan Brown and Dennis McClain (USGS) in furnishing stage data. Lyle Sendlein, Susan Hendricks, and Steve Workman offered helpful advice. 


\section{TABLE OF CONTENTS}

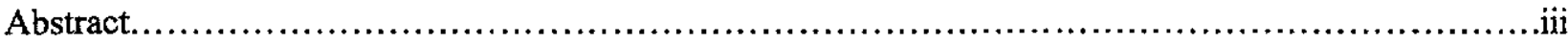

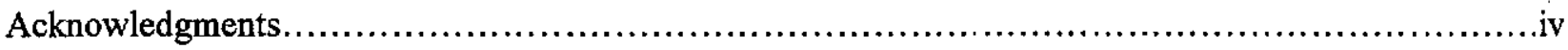

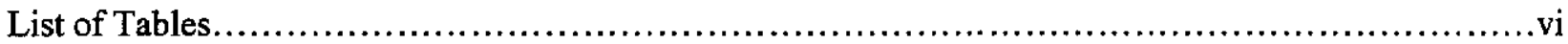

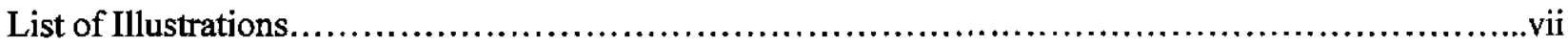

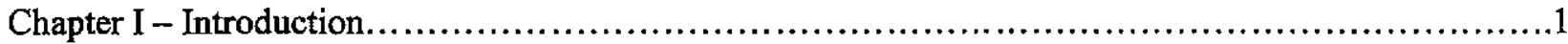

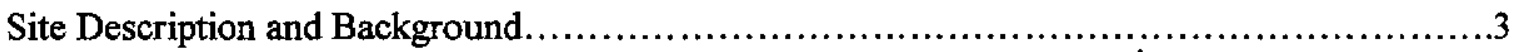

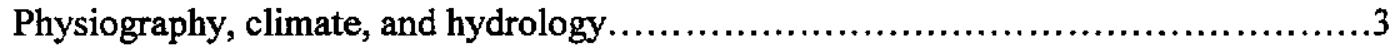

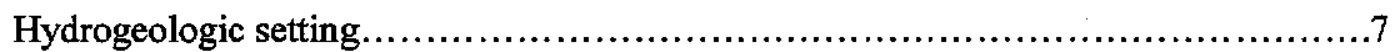

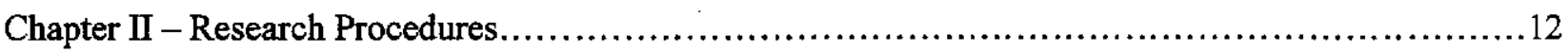

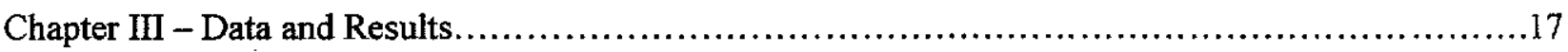

Hydraulic Gradients-Bayou Creek................................................ 17

Hydraulic Gradients-Little Bayou Creek...........................................19

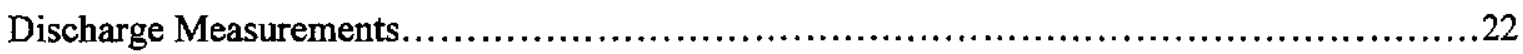

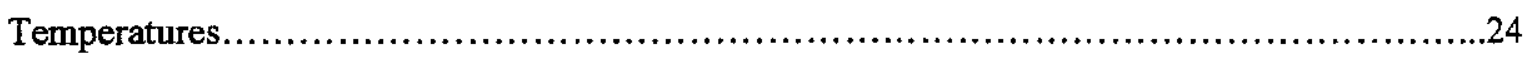

Hydrochemical Parameters and Mixing Modeling..................................... 31

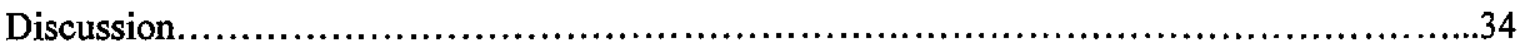

Losing or no-net-discharge reaches of creeks.................................... 34

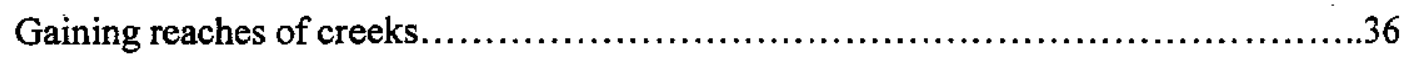

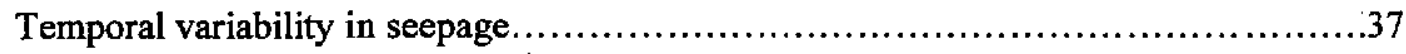

Variability in hydrochemical parameters...........................................

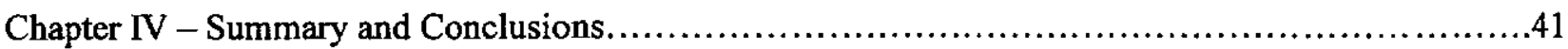

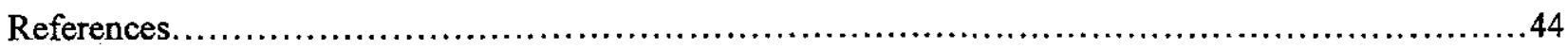




\section{LIST OF TABLES}

Table 1. Well and piezometer construction data......................................................

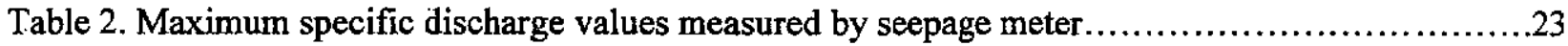

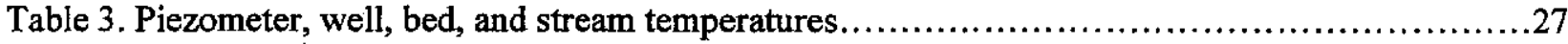

Table 4. Solute and oxygen-18 concentrations in stream (S suffix) and well (Y suffix) water.............30

Table 5. Models of ground-water/stream-water mixing along Bayou and Little Bayou Creeks............32

Table 6. Concentration factors for evaporation of BB5Y ground water to yield BB5 surface water........39 


\section{LIST OF ILUSTRATIONS}

Figure 1. Site map showing monitoring locations and the approximate line of cross section (A-A') shown in Figure 4. Stippled areas denote TCE concentrations $\geq 5 \mu \mathrm{g} \mathrm{L}^{-1}$ and hachured areas denote ${ }^{99} \mathrm{Tc}$ activities $\geq 25 \mathrm{pCi} \mathrm{L}^{-1}$ (from Jacobs EM Team, 1998).......................................... 4

Figure 2. Precipitation at Barkley Airfield, Paducah, Kentucky (from unpublished NWS data).........6

Figure 3. Ohio River stage at Metropolis, Illinois (from provisional USGS data) ...................6

Figure 4. Hydrostratigraphic cross-section oriented approximately along line A-A' shown in Figure 1 (from A.F. Diefendorf, Oak Ridge National Laboratory). Equipotential interval $=1.5 \mathrm{~m}(5$ feet). Arrows indicate approximate directions (but not magnitudes) of ground-water flow when the Ohio River is at pool

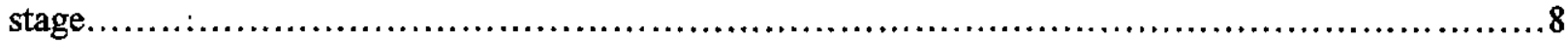

Figure 5(a). Hydraulic heads in the RGA on March 24-25, 1997 (contour interval $=0.25 \mathrm{~m}$ ).........9

Figure 5(b). Hydraulic heads in the RGA on September 24-25, 1997 (contour interval $=1 \mathrm{~m}$ )........10

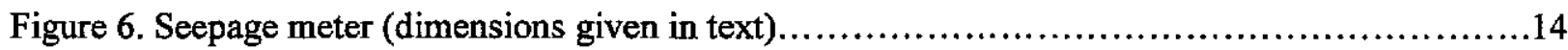

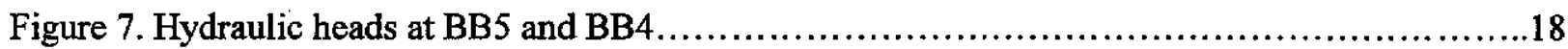

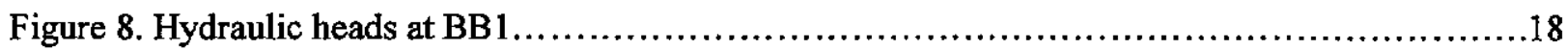

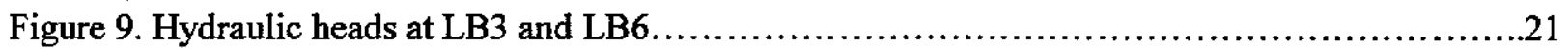

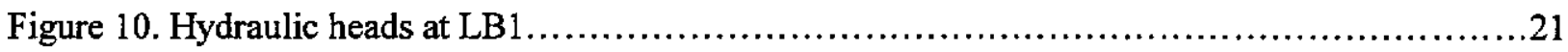

Figure 11. Streamflow along selected reaches of Little Bayou Creek..............................25

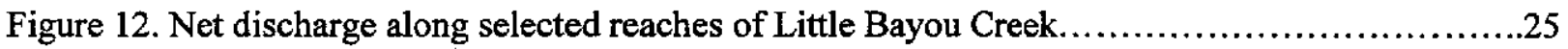

Figure 13. Air, stream, piezometer, and well temperatures at LB1 ............................26

Figure 14. Bed temperatures along downstream reach of Little Bayou Creek with stream and air

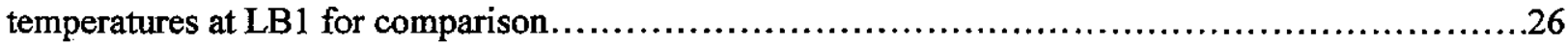




\section{INTRODUCTION}

Studies of aquifer-stream interactions have commonly focused on delineating losing and gaining reaches of streams (Silliman and Booth, 1993; Constantz, 1998); quantifying baseflow (Meyboom, 1961; Turner and Macpherson, 1990, Pearce, 1990); modeling bank storage (Cooper and Rorabaugh, 1963; Hibbs, 1993; Squillace, 1996); mapping flow paths in alluvial aquifers (Larkin and Sharp, 1992); and delineating flow and chemical evolution in the riparian and hyporheic zones (Lowrance, 1992; Hendricks and White, 1991; Wroblicky et al., 1998). Interactions among ground water, rivers, and small (first- and second-order) tributaries have received relatively little attention. In tributary watersheds, both ground water and the tributary are likely to flow toward the river, and the tributary should lose water as it traverses the recharge zone and gain water in the discharge zone (Freeze and Cherry, 1979, p. 205). Flooding along the river can result in slackwater conditions along the tributary, and flooding along either the tributary or the river can temporarily reverse hydraulic gradients in the aquifer.

Understanding interactions among ground water, rivers, and tributaries is potentially important for assessing pollutant mobility. Ground water can carry significant loads of non-point-source pollutants (e.g., pesticides and nutrients) to streams (Squillace et al., 1993; Böhlke and Denver, 1995; Job and Simons, 1996). Industrial point sources can also contaminate alluvial aquifers or discharge directly to rivers or tributaries (Winter et al., 1998). Surface-water contaminants can move into alluvial aquifers during floods, then return to streams under baseflow conditions (Squillace et al., 1993). However, contaminants can be naturally attenuated in riparian or hyporheic zones if residence times are sufficiently long and geochemical conditions are suitable (Lowrance, 1992; Böhlke and Denver, 1995; Lorah et al., 1997). Concerns about water quality in alluvial aquifers and the impacts of ground-water contaminants on surface-water ecosystems are motivating researchers and regulators to examine contaminant fluxes from an integrated (watershed) perspective (Job and Simons, 1996; Ward, 1996; Winter et al., 1998).

Multiple techniques are available for assessing ground-water/stream interactions. Examples include physical methods (seepage meters and piezometers in stream beds, numerical models, and 
geophysical surveys), hydrochemical (e.g., isotope) methods, and hybrid methods (near-stream groundwater sampling and flow measurements, hydrograph separation, and land use functions) (U.S. Environmental Protection Agency, 1991). Thermal monitoring can also be useful for delineating gaining and losing reaches of streams because temporal variability in stream temperature along gaining reaches should be less than along losing reaches (Silliman and Booth, 1993; Constantz, 1998). Moreover, the difference between ground-water and stream temperatures along gaining reaches can exceed $5^{\circ} \mathrm{C}$ in winter and $10^{\circ} \mathrm{C}$ in summer (White et al., 1987). The combined use of physical, hydrochemical, and thermal techniques is likely to yield more information than any single method (Hibbs, 1993; Rice and Hornberger, 1998; Constantz, 1998).

In this paper, we examine interactions among ground water, the Ohio River, and tributary streams in adjoining watersheds. The U.S. Department of Energy's (DOE) Paducah Gaseous Diffusion Plant (PGDP), a National Priorities List site, is bounded by Little Bayou and Bayou Creeks, which are first- and second-order streams in McCracken County, Kentucky. Since 1952, PGDP has produced enriched uranium for use in nuclear reactors. Releases of trichloroethene (TCE, which was used extensively as a degreasing solvent) and technetium- $99\left({ }^{99} \mathrm{Tc}\right.$, a byproduct of uranium reprocessing) to ground water have resulted in plumes extending several kilometers offsite toward the Ohio River (Clausen et al., 1992). We hypothesized that infiltration from Bayou Creek could mobilize contaminants beneath PGDP and contaminated ground water could discharge to Little Bayou Creek. We discuss the use of physical, thermal, and hydrochemical techniques to (1) delineate gaining and losing reaches of the creeks at various times and (2) quantify mixing of waters from various sources during a two-year period. Herein, we define a gaining reach as one where ground water discharges directly to the stream, rather than upwelling to mix with stream water advecting within the bed. This latter scenario represents the hydrologic definition of the hyporheic zone given by White (1993). 


\section{Site Description and Background}

Physiography, climate, and hydrology

The study area is located in the Gulf Coastal Plain $\sim 16 \mathrm{~km}$ west of Paducah, Kentucky (Figure 1). The 2,788-ha West Kentucky Wildlife Management Area surrounds PGDP and extends to the Ohio River, $\sim 5 \mathrm{~km}$ northeast. Other land use in the study area includes the Tennessee Valley Authority (TVA) Shawnee Plant (a coal-fired generating station), farms, rural residences, and businesses. Land-surface elevations range from 107 to $116 \mathrm{~m}$ above mean sea level (amsl) around PGDP to $88 \mathrm{~m}$ amsl at the river (pool elevation). PGDP is situated on the drainage divide between Little Bayou Creek to the east and Bayou Creek to the west. Bayou Creek is a perennial, $14.5-\mathrm{km}$ stream whose basin encompasses 4,764 ha, extending from $\sim 4.0 \mathrm{~km}$ south of PGDP to the river. Little Bayou Creek, with a basin of $\sim 2,400 \mathrm{ha}$, originates south of PGDP and flows northward for $10.5 \mathrm{~km}$. Prior to construction of the Shawnee Plant, Little Bayou Creek was a separate tributary of the Ohio River. Between 1953 and 1971, a 2.5-km reach was channelized around the Shawnee Plant and connected to Bayou Creek $\sim 340 \mathrm{~m}$ south of the river. Most of the flow in both creeks originates from water that is pumped from the river to PGDP, used in industrial processes, and then discharged via outfalls. In the vicinity of PGDP, effluent constitutes $\sim 85 \%$ of the water in Bayou Creek and almost $100 \%$ of the water in Little Bayou Creek at baseflow (CH2M Hill, 1992). Discharges averaged $\sim 1.5 \times 10^{4} \mathrm{~m}^{3} \mathrm{~d}^{-1}$ to Bayou Creek and $\sim 2.7 \times 10^{3} \mathrm{~m}^{3} \mathrm{~d}^{-1}$ to Little Bayou from October 1987 through November 1988.

The climate of the lower Ohio Valley is humid-continental. The average annual air temperature (1961-1990) at Barkley Airfield, $\sim 6 \mathrm{~km}$ southeast of PGDP, is $14.0^{\circ} \mathrm{C}$, with the lowest monthly average temperature in January $\left(0.3^{\circ} \mathrm{C}\right)$ and the highest in July $\left(26^{\circ} \mathrm{C}\right)$ (Illinois State Water Survey, unpublished data). Precipitation (annual average $1.25 \mathrm{~m}$ ) is relatively evenly distributed throughout the year, with January the driest month $(83.1 \mathrm{~mm})$ and April the wettest $(127 \mathrm{~mm})$. Using the method of Thornthwaite 
Figure 1. Site map showing monitoring locations and the approximate line of cross section (A-A') shown in Figure 4. Stippled areas denote TCE concentrations $\geq 5 \mu \mathrm{g} \mathrm{L}^{-1}$ and hachured areas denote ${ }^{99} \mathrm{Tc}$ activities $\geq 25 \mathrm{pCi} \mathrm{L}^{-1}$ (from Jacobs EM Team, 1998).

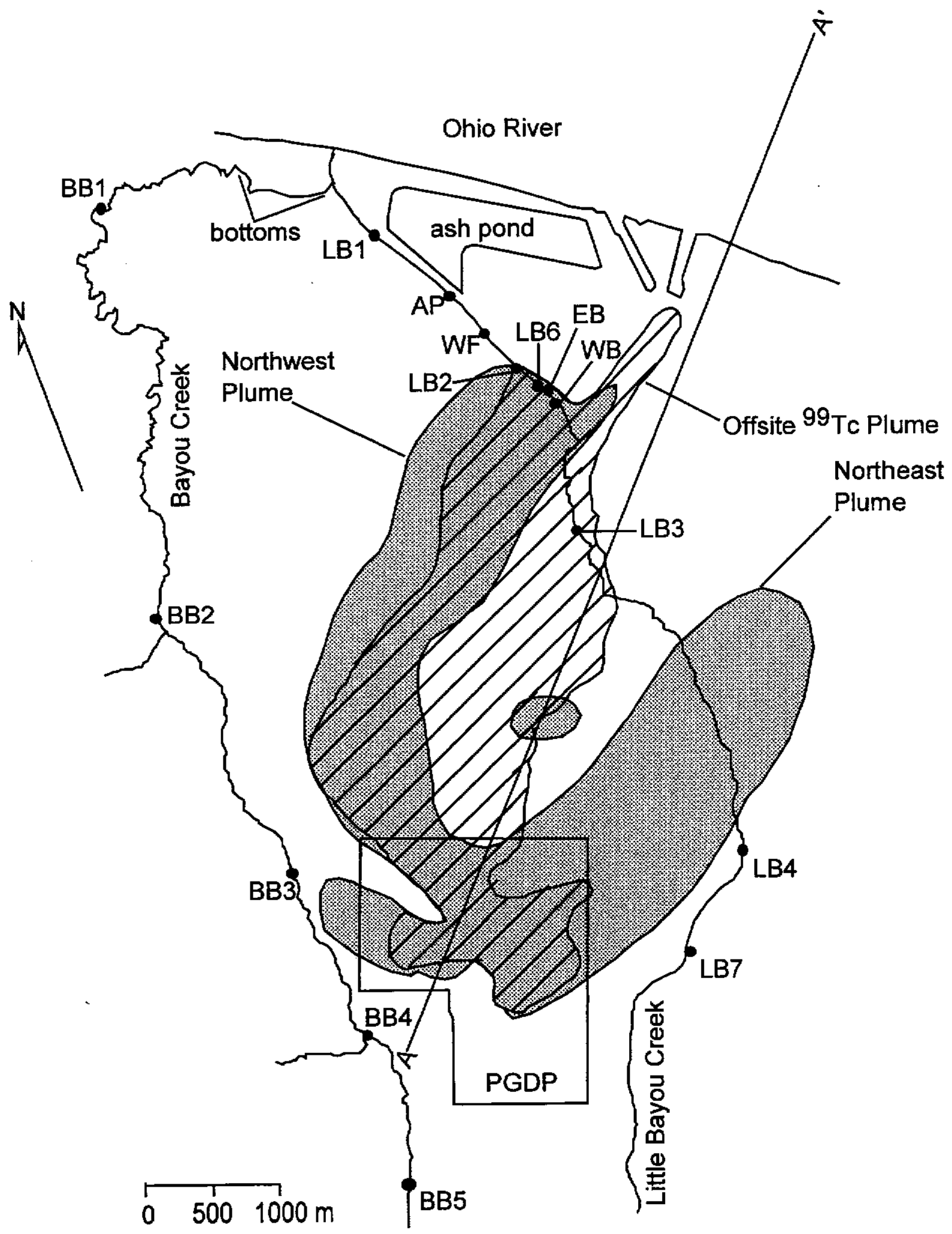


and Mather (1957) for 1969-1989 data, CH2M Hill (1992) calculated that potential evapotranspiration exceeds actual evapotranspiration (and precipitation) from June through September and that no water is available for infiltration or runoff from June through October. During our study, the minimum air temperature at Barkley Airfield was $-19^{\circ} \mathrm{C}$ on January 11,1997 , and the maximum was $37^{\circ} \mathrm{C}$ on July 27, 1997 (National Weather Service [NWS], unpublished data). Precipitation from July 22, 1996, through October 12, $1997(1.76 \mathrm{~m}$ ) exceeded the normal amount for the period by $0.26 \mathrm{~m}$ (Figure 2). From February 26 through March 3, 1997, Barkley Airfield recorded $0.20 \mathrm{~m}$ of rainfall, while other parts of the lower Ohio and Tennessee Valleys received 0.076 to $0.30 \mathrm{~m}$. Consequently, the Ohio River was in flood (above $\sim 97 \mathrm{~m}$ amsl) at Metropolis, Illinois, $\sim 5.6 \mathrm{~km}$ upriver of the mouth of Bayou Creek, from March 1 through April 3 (Figure 3) (U.S. Geological Survey [USGS] and NWS, unpublished data). The river crested at Metropolis at $102.2 \mathrm{~m}$ amsl on March 11. The crest at Paducah, $15 \mathrm{~km}$ upriver of Metropolis, was the highest since February 13, 1950 (NWS, unpublished data).

Prior work provides limited information on ground-water/stream interactions in the study area. Evaldi and McClain (1989) sought to identify losing and gaining reaches of Bayou and Little Bayou Creeks under baseflow conditions on August 15-16, 1989. Velocities were measured by wading with current meters at 150 to $180-\mathrm{m}$ intervals along the creeks. Volumetric flow rates, which were calculated according to the cross-section method (Rantz et al., 1982), were relatively constant along most of Little Bayou Creek, but increased within $\sim 3.7 \mathrm{~km}$ of its mouth. Bayou Creek lost flow over the entire gaged reach (from 7.6 to $3.0 \mathrm{~km}$ upstream of the mouth). Final flow rates were $4.5 \times 10^{3} \mathrm{~m}^{3} \mathrm{~d}^{-1}$ for Little Bayou Creek $\left(1.7 \mathrm{~km}\right.$ from the mouth) and $1.4 \times 10^{4} \mathrm{~m}^{3} \mathrm{~d}^{-1}$ for Bayou Creek (3.1 km from the mouth) (Evaldi and McClain, 1989). Temperature measurements corroborated gaging data. Temperatures along Bayou Creek ranged from 22.3 to $31.3^{\circ} \mathrm{C}$, while temperatures along Little Bayou Creek ranged from 21.0 to $24.9^{\circ} \mathrm{C}$ over the first $4.8 \mathrm{~km}$ before decreasing to $19.5^{\circ} \mathrm{C}$ along the last $600 \mathrm{~m}$. Elevated temperatures 1 to $2 \mathrm{~km}$ downstream of outfalls probably resulted from effluent discharge (Roy et al., 1996). 


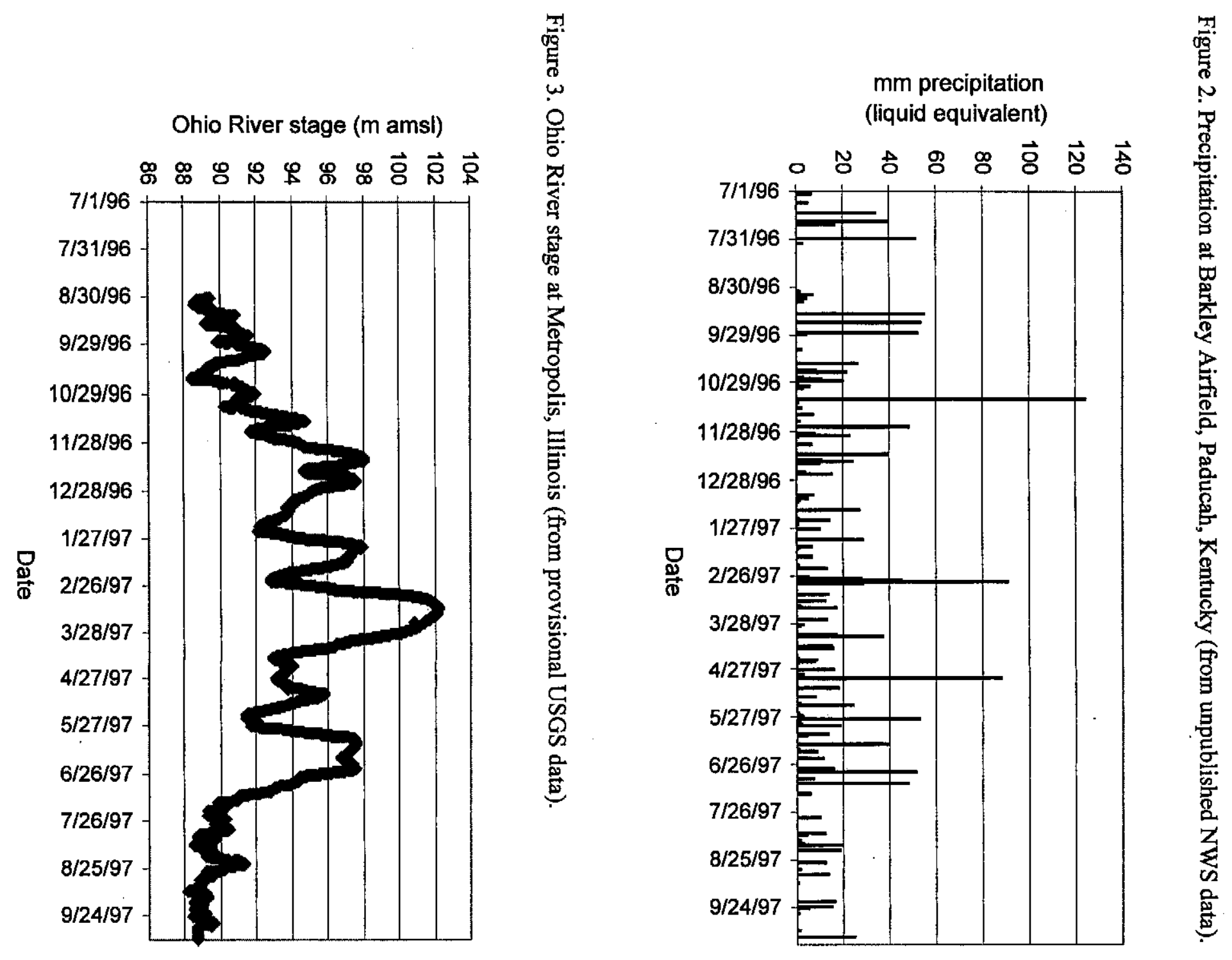




\section{Hydrogeologic setting}

The Bayou and Little Bayou Creek watersheds are underlain by a 90 to 120 -m-thick sequence of marginal marine to continental sediments, which unconformably overlie Mississippian carbonate bedrock (Clausen et al., 1992) (Figure 4). This clastic wedge dips south-southwest toward the axis of the Mississippi Embayment. The McNairy Formation (Cretaceous), which subcrops beneath PGDP at depths of $\sim 21$ to $30 \mathrm{~m}$, consists of upper and lower clayey fine sands locally separated by silty clay (Davis, 1996). Incision of the ancestral Tennessee River removed much of the Tertiary strata between the site of PGDP and the present Ohio River. Above this unconformity, the Continental Deposits (PliocenePleistocene) form an upward-fining, valley-fill sequence. Chert gravel in a poorly sorted sand-silt matrix is overlain by sand and gravel lenses interbedded with lacustrine clays (Clausen et al., 1992). The Continental Deposits are mantled by loess and by alluvium adjacent to streams and the river. In the Bayou Creek watershed south of PGDP, the clayey Porters Creek Formation (Paleocene) is overlain by terrace gravels older and less extensive than those of the lower Continental Deposits.

Previous investigations in the vicinity of PGDP have provided a conceptual framework for ground-water flow within the Continental Deposits, although flow within deeper units is less well understood. Flow is predominantly vertical (hydraulic gradient $\sim 1$ ) within the upper Continental Deposits (the Upper Continental Recharge System [UCRS] of Clausen et al. [1992]). Within the semi-confined lower Continental Deposits (known informally as the Regional Gravel Aquifer [RGA]), ground water tends to flow north-northeastward toward the Ohio River at an average hydraulic gradient of 0.0006 (Clausen et al., 1995). However, Ohio River flooding can cause gradient reversals. Figure 5 depicts hydraulic heads in RGA monitoring wells on March 24-25, 1997, when the river was $101 \mathrm{~m}$ amsl at Metropolis, and September 24-25, 1997, when the Ohio River was 88.5 to $89.3 \mathrm{~m}$ amsl at Metropolis (Lockheed Martin Energy Systems and USGS, unpublished data). In March, the RGA was virtually stagnant as far as $6 \mathrm{~km}$ from the river, with hydraulic heads decreasing to the south-southeast. Flow 
Figure 4. Hydrostratigraphic cross-section oriented approximately along line A-A' shown in Figure 1 (from A.F. Diefendorf, Oak Ridge National Laboratory). Equipotential interval $=1.5 \mathrm{~m}$ (5 feet). Arrows indicate approximate directions (but not magnitudes) of ground-water flow when the Ohio River is at pool stage.

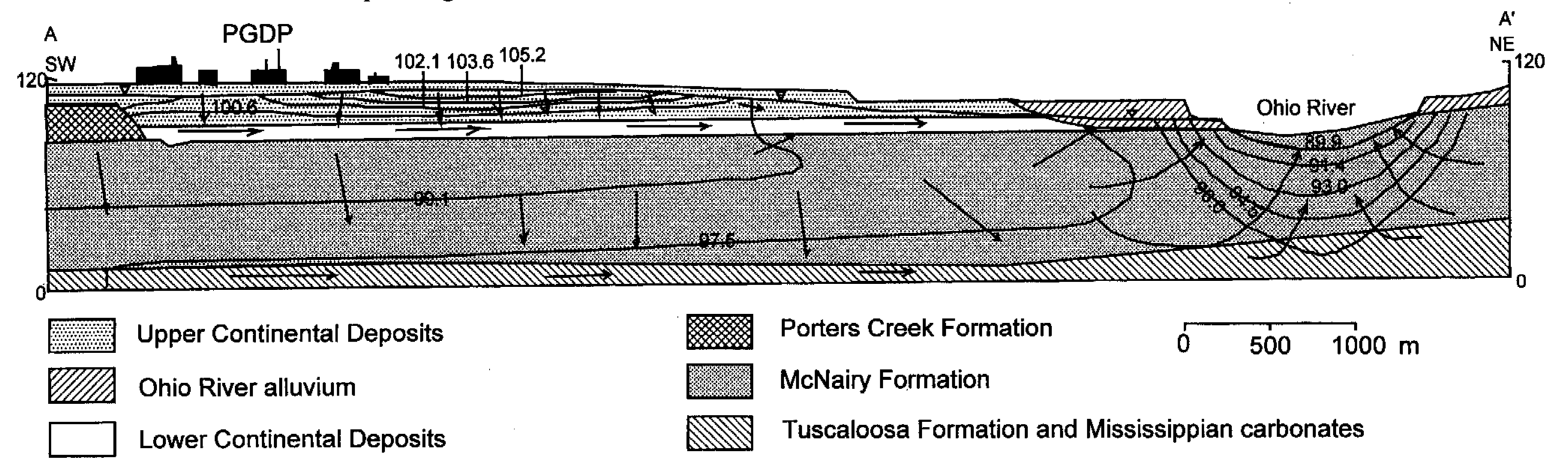


9

Figure 5(a). Hydraulic heads in the RGA on March 24-25, 1997 (contour interval $=0.25 \mathrm{~m}$ ).

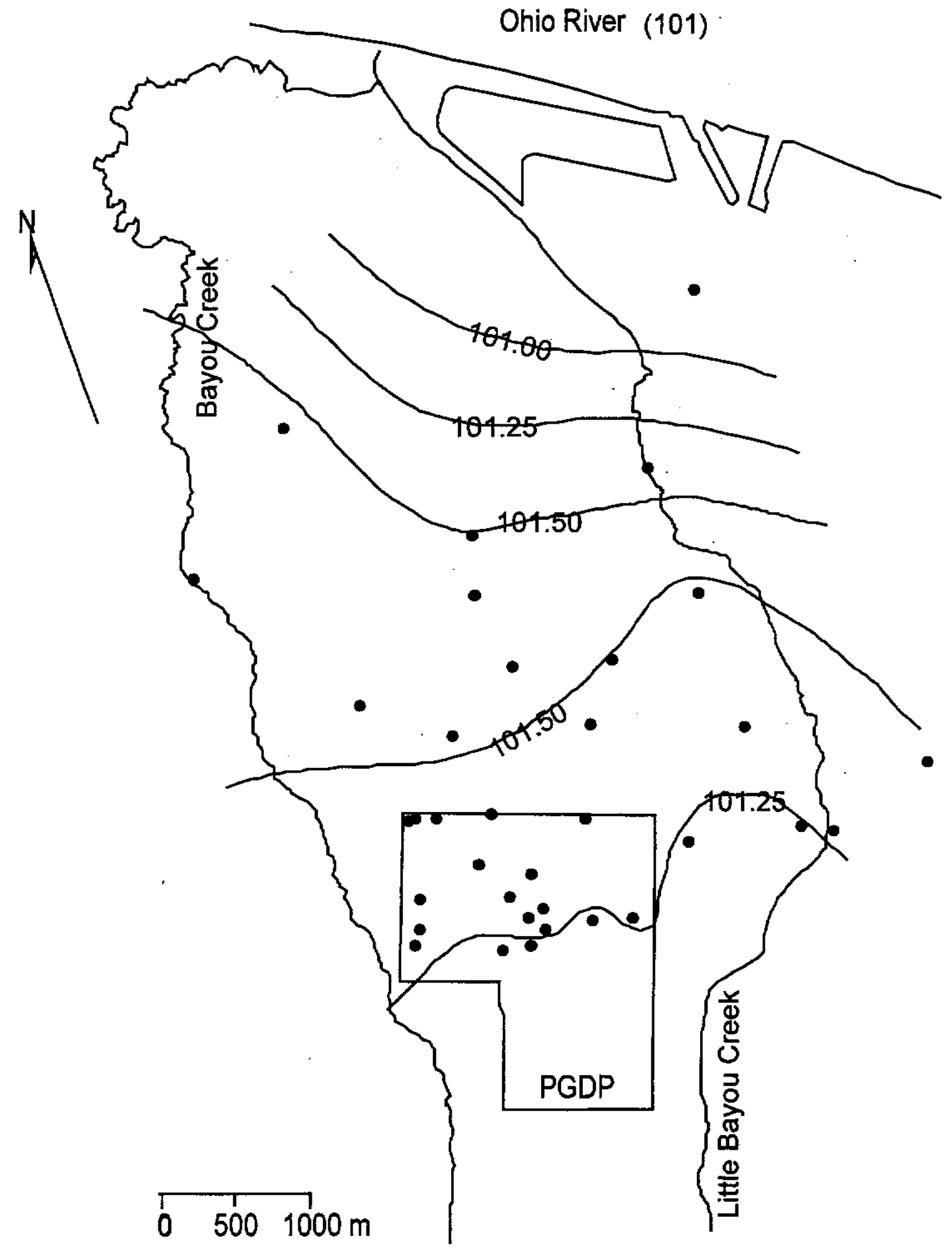


within the RGA may also be affected by an east-west trending paleochannel beneath PGDP (Clausen et al., 1992) and by faults striking northeast-southwest (Langston et al., 1998). Some flow occurs downward from the RGA into the McNairy Formation beneath PGDP and upward from the McNairy near the river (Davis, 1996).

Three major contaminant plumes emanate from PGDP and extend within the RGA toward the Ohio River (Figure 1). The Northwest Plume, which appears to originate from multiple source areas, is aligned with the inferred paleochannel and faults mentioned above. The far-field portion of the Northwest Plume may divide around ash-settling ponds at the Shawnee Plant, but the width of the plume probably also reflects flood-induced variability in flow directions in the RGA, consistent with seasonally fluctuating TCE and ${ }^{99} \mathrm{Tc}$ concentrations in monitoring wells (Clausen et al., 1992). Data of Evaldi and McClain (1989) suggest that the Northwest Plume and the Offsite ${ }^{99} \mathrm{Tc}$ Plume pass beneath a gaining reach of Little Bayou Creek, whereas the Northeast Plume passes beneath a reach having negligible changes in flow. These data are consistent with measurements of CH2M Hill $(1991,1992)$, who found that TCE and ${ }^{99} \mathrm{Tc}$ concentrations increased above background along Little Bayou Creek in the vicinity of the Northwest and Offsite ${ }^{99} \mathrm{Tc}$ Plumes. 


\section{RESEARCH PROCEDURES}

We conducted field investigations monthly from July 22, 1996, through October 12, 1997 (except for March 1997), with supplemental measurements on July 10,1998, at multiple sites in the Bayou and Little Bayou Creek watersheds (Figure 1). At five sites in each watershed, we installed and monitored clusters of two to four drive-point piezometers in the stream bed. Piezometers were fabricated from 1-1/4 inch nominal black steel pipe ( $0.033-\mathrm{m}$ inside diameter [D], 1.22 to $1.83 \mathrm{~m}$ long) that was crimped by a hydraulic press along the bottom $0.1 \mathrm{~m}$ and perforated with $\sim 800.4-\mathrm{mm}$-diameter holes along the next $0.15 \mathrm{~m}$. One or two stream-bank monitoring wells consisting of 2-inch nominal (0.021-m ID) PVC pipe were installed at three sites in each watershed. Screened intervals in paired wells were vertically offset by $1.5 \mathrm{~m}$. Piezometer and well locations are prefixed by BB for (Big) Bayou and LB for Little Bayou; piezometers at each location were given the suffixes $A$ through $G$ and wells the suffixes $Y$ and $Z$. Depths and perforated (screened) intervals for piezometers and wells are listed in Table 1.

We measured water levels and temperatures in piezometers and wells, stream temperatures, and air temperatures with a YSI Model 3000 T-L-C meter (Yellow Springs Instrument Co., Inc., Yellow Springs, Ohio). Following White et al. (1987), we also measured stream-bed and bank temperatures with 1.0 to $1.3-\mathrm{m}$ long, stainless-steel thermistor probes connected to a YSI 4600 Precision Thermometer. Hydraulic heads and stream stages were referenced to top-of-casing elevations, which were surveyed with a Trimble 4600 global positioning system unit for wells BB5Y, BB1Y, LB6Y, and LB1Y and with a Pentax total station for other wells and piezometers.

During most visits to the study area, we installed portable seepage meters at various locations. The design of the seepage meter was modified by Susan Hendricks (Murray State University, personal communication) from the original version of Lee (1977) (Figure 6). One end of a 0.15-m length of 4-inch nominal (0.10-m ID) PVC pipe was glued with epoxy to a 2.4-mm thick Plexiglas ${ }^{\mathrm{TM}}$ sheet and sealed with caulk. A hole in the top of the sheet, into which a 00 rubber stopper could be inserted, allowed evacuation of air during insertion into the stream bed. Another hole $(0.095-\mathrm{m}$ diameter) was drilled into the side of 
Table 1. Well and piezometer construction data. Well or Latitude ${ }^{\star *} \quad$ Longitude $^{* *}$ Location piezo.*

\begin{tabular}{|c|c|c|c|c|c|c|c|}
\hline & . & & & $\begin{array}{l}\text { elev. } \\
\text { (m amsi) }\end{array}$ & $\begin{array}{l}\text { depth } \\
\text { (m) }\end{array}$ & $\begin{array}{l}\text { perfed interval } \\
\text { (m amsl) }\end{array}$ & $\begin{array}{l}\text { perf'ed interval } \\
\text { (m amsl) }\end{array}$ \\
\hline BB1A & N $37^{\circ} 10^{\prime} 22^{\prime \prime}$ & $W 88^{\circ} 49^{\prime} 10^{\prime \prime}$ & Midstream & 94.9 & 0.6 & 94.4 & 94.7 \\
\hline BB1B & & & Midstream & 94.9 & 0.9 & 94.1 & 94.4 \\
\hline BB1Y & & & W bank & 98.1 & 6.1 & 92.0 & 92.7 \\
\hline BB1Z & & & W bank & 98.1 & 4.6 & 93.5 & 94.3 \\
\hline BB2A & N $37^{\circ} 08^{\prime} 39^{\prime \prime}$ & W $88^{\circ} 49^{\prime} 40^{\prime \prime}$ & Midstream & 100.9 & 1.2 & 99.9 & 100.2 \\
\hline BB2B & & & Midstream & 100.9 & 1.4 & 99.7 & 100.0 \\
\hline BB3A & N $37^{\circ} 07^{\prime} 26^{\prime \prime}$ & W $88^{\circ} 49^{\prime} 26^{\prime \prime}$ & W bank edge & 105.8 & 1.2 & 104.7 & 105.0 \\
\hline $\begin{array}{l}\text { BB3B } \\
\text { BB3Y }\end{array}$ & & & $\begin{array}{l}\text { W bank edge } \\
E \text { bank }\end{array}$ & $\begin{array}{l}105.7 \\
108.6\end{array}$ & $\begin{array}{r}1.3 \\
12.0\end{array}$ & $\begin{array}{r}104.5 \\
96.6\end{array}$ & $\begin{array}{r}104.8 \\
97.3\end{array}$ \\
\hline BB4A & N $37^{\circ} 06^{\prime} 42^{\prime \prime}$ & W $88^{\circ} 49^{\prime} 26^{\prime \prime}$ & $\begin{array}{l}\text { Midstream } \\
\text { (tributary) }\end{array}$ & 108.8 & 0.7 & 108.2 & 108.5 \\
\hline BB5B & N $37^{\circ} 05^{\prime} 59^{\prime \prime}$ & $W 88^{\circ} 49^{\prime} 28^{\prime \prime}$ & Midstream & 111.5 & 0.9 & 110.6 & 110.9 \\
\hline BB5C & & & Midstream & 111.5 & 0.8 & 110.7 & 111.0 \\
\hline BB5Y & & & W bank & 114.9 & 6.1 & 108.8 & 109.6 \\
\hline BB5Z & & & W bank & 114.9 & 4.6 & 110.4 & 111.1 \\
\hline LB1D & $N 37^{\circ} 09^{\prime} 48^{\prime \prime}$ & W $88^{\circ} 47^{\prime} 52^{\prime \prime}$ & W bank edge & 92.9 & 0.8 & 92.2 & 92.5 \\
\hline LB1E & & & $W$ bank edge & 92.9 & 1.0 & 92.0 & 92.3 \\
\hline LB1F & & & E bank bar & 93.6 & 1.0 & 92.7 & 93.0 \\
\hline LB1G & & & E bank bar & 93.7 & 1.3 & 92.5 & 92.8 \\
\hline LB1Y & & & W bank & 98.3 & 8.4 & 89.9 & 90.7 \\
\hline LB1Z & & & W bank & 98.4 & 7.0 & 91.3 & 92.1 \\
\hline LB2D & N $37^{\circ} 09^{\prime} 06^{\prime \prime}$ & $W 88^{\circ} 47^{\prime} 27^{\prime \prime}$ & W bank edge & 95.6 & 0.9 & 94.8 & 95.1 \\
\hline LB2E & & & W bank edge & 95.6 & 0.5 & 95.2 & 95.5 \\
\hline LB6A & N $37^{\circ} 08^{\prime} 59^{\prime \prime}$ & $W 88^{\circ} 47^{\prime} 22^{\prime \prime}$ & W bank edge & 95.6 & 1.0 & 94.7 & 95.0 \\
\hline LB6B & & & W bank edge & 95.7 & 0.8 & 95.0 & 95.3 \\
\hline LB6Y & & & W bank & 98.1 & 7.2 & 90.9 & 91.7 \\
\hline LB6Z & & & W bank & 98.1 & 5.8 & 92.3 & 93.0 \\
\hline LB3A & N $37^{\circ} 08^{\prime} 22^{\prime \prime}$ & $W 88^{\circ} 47^{\prime} 25^{\prime \prime}$ & W bank edge & 99.0 & 0.5 & 98.6 & 98.9 \\
\hline LB3B & & & W bank edge & 99.0 & 0.8 & 98.3 & 98.6 \\
\hline LB4A & $N 37^{\circ} 06^{\prime} 49^{\prime \prime}$ & $W 88^{\circ} 47^{\prime} 12^{\prime \prime}$ & Midstream & 105.9 & 0.5 & 105.5 & 105.8 \\
\hline LB4B & & & Midstream & 105.9 & 0.6 & 105.4 & 105.7 \\
\hline LB7Y & N $37^{\circ} 06^{\prime} 30^{\prime \prime}$ & $W 88^{\circ} 47^{\prime} 40^{\prime \prime}$ & E bank & 111.3 & 7.3 & 104.0 & 105.5 \\
\hline
\end{tabular}

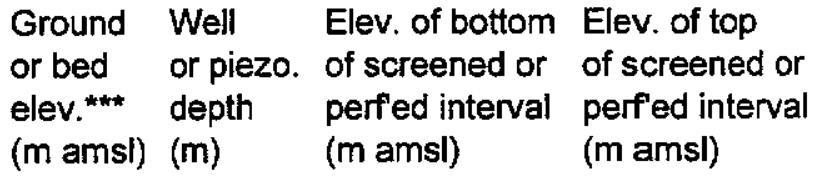

94 
Figure 6. Seepage meter (dimensions given in text). 
the pipe $\sim 0.025 \mathrm{~m}$ below the sheet, then tapped and fitted with a 0.125 -inch NPT nipple wrapped with Teflon ${ }^{\mathrm{TM}}$ tape. A $0.3-\mathrm{m}$ length of Tygon ${ }^{\mathrm{TM}}$ tubing (6.4-mm ID) was attached to the outlet and connected at the other end to a \#9 stopper, which was fitted into a 0.3-m length of 1:5-inch nominal (0.037-m ID) PVC pipe. To collect seepage, the meter was placed into the bed up to the nipple. A non-lubricated condom was flattened to expel air and placed onto the large stopper, which was inserted into the $0.3-\mathrm{m}$ long PVC pipe to shield the condom, then the small stopper was inserted into the top of the meter. We calculated specific discharge $\left(\mathrm{Lt}^{-1}\right)$ as

$$
q=Q / A
$$

where $Q$ is the volumetric discharge rate $\left(\mathrm{L}^{3} \mathrm{t}^{-1}\right)$ and $\mathrm{A}$ is the cross-sectional area of the seepage meter $\left(0.0079 \mathrm{~m}^{2}\right)$

We gaged stream flow at selected sites by wading with a Flo-Mate Model 2000 portable flow meter (Marsh-McBirney, Inc., Frederick, Maryland). The electromagnetic sensor was attached to a topsetting rod set for the six-tenths method, in which velocity measured at $60 \%$ of the stream depth is taken as the vertical mean velocity (Rantz et al., 1982). We secured a measuring tape across the stream and measured depth and velocity at width increments of 0.076 to $0.61 \mathrm{~m}$. Stream discharge $Q_{\mathrm{s}}$ was calculated as

$$
\mathrm{Q}_{\mathrm{s}}=\Sigma(\mathrm{a} \mathbf{v})
$$

where $\mathrm{a}$ is the area of an individual partial cross-section $\left(\mathrm{L}^{2}\right)$ and $\mathrm{v}$ is the corresponding mean velocity normal to the partial area $\left(\mathrm{L} \mathrm{t}^{-1}\right)$ (Rantz et al., 1982). For comparison with seepage-meter measurements, we estimated the net specific discharge $q_{n}$ along a reach as

$$
\mathrm{q}_{\mathrm{n}}=\frac{\left(\mathrm{Q}_{\underline{\underline{u}}} / \mathrm{w}_{\mathrm{u}}-\mathrm{Q}_{\mathrm{d}} / \mathrm{w}_{\underline{\alpha}}\right)}{\mathrm{L}}
$$

where the subscripts $u$ and $d$ refer to upstream and downstream transects, respectively, $w$ is the width of a transect, and $\mathrm{L}$ is the length of the reach.

In January, May, August, and October 1997, we sampled "Y" wells and adjoining reaches of the creeks for field parameters (Eh, $\mathrm{pH}$, dissolved oxygen, and alkalinity), metals and metalloids, anions, 
oxygen-18, and (at some sites) volatile organic compounds (VOCs) and ${ }^{99} \mathrm{Tc}$. In January 1997, we collected stream- and ground-water samples only at locations BB5, BB1, LB6, and LB1 because well LBTY had not been drilled and because of difficulties in pumping well BB3Y. We also collected streamand spring-water samples for VOCs along Little Bayou Creek in July 1998. We report herein the results of analyses for $\mathrm{B}, \mathrm{Cl}^{-},{ }^{18} \mathrm{O}, \mathrm{TCE}$, and ${ }^{99} \mathrm{Tc}$. Boron is a solute associated with fly-ash leachate (Simsiman et al., 1987; Davidson and Bassett, 1993), while $\mathrm{Cl}^{-}$is a relatively conservative tracer of solute movement in dilute surface and ground waters (Hem, 1992). At temperatures $<50^{\circ} \mathrm{C},{ }^{18} \mathrm{O}$ is a conservative tracer of water movement beneath the upper soil zone. Concentrations depend upon the isotopic composition of precipitation and the extent of evaporation, which differentially enriches liquid water in ${ }^{18} \mathrm{O}$ (Freeze and Cherry, 1979).

We sampled ground water with a submersible pump in January and with a peristaltic pump subsequently. Each well was pumped at a rate of $\sim 10 \mathrm{~mL} \mathrm{~s}^{-1}$ and sampled when temperature, $\mathrm{pH}$, and Eh had stabilized. Both ground-water samples and stream-water grab samples were passed through disposable in-line filters $(0.45-\mu \mathrm{m}$ pore size $)$. We collected anion samples in $500-\mathrm{mL}$ polyethylene bottles and ${ }^{18} \mathrm{O}$ samples in $500-\mathrm{mL}$ glass bottles without preservatives. Metals, metalloids, and ${ }^{99} \mathrm{Tc}$ were collected in polyethylene bottles and preserved with $6 \mathrm{~N} \mathrm{HNO}_{3}(5 \mathrm{~mL}$ acid per $500 \mathrm{~mL}$ bottle for metals and metalloids; $10 \mathrm{~mL}$ acid per $1000 \mathrm{~mL}$ for ${ }^{99} \mathrm{Tc}$ ). VOCs were collected in $40-\mathrm{mL}$ amber glass vials, acidified with two drops $6 \mathrm{~N} \mathrm{HCl}$, and sealed with Teflon ${ }^{\mathrm{TM}}$-backed silicone septa without headspace. All samples were stored at $\sim 4^{\circ} \mathrm{C}$ prior to analyses. Metals and metalloids were analyzed by inductively coupled plasma spectrophotometry and anions by ion chromatography at the Kentucky Geological Survey and at Quanterra, Inc. (Earth City, Missouri). VOCs were analyzed by gas chromatography and ${ }^{99} \mathrm{Tc}$ by liquid scintillation counting at Quanterra. Oxygen-18 samples were analyzed by mass spectrometry at the University of Georgia with a precision of $0.15 \%$. We report ${ }^{18} \mathrm{O}$ in \% deviation from a value of 0 for standard mean ocean water (SMOW) using the $\delta$ notation, where R refers to the isotopic ratio $\left({ }^{18} \mathrm{O} /{ }^{16} \mathrm{O}\right.$ ):

$$
\delta=\left(\left(R_{\text {sample }} / R_{\text {standard }}\right)-1\right) \times 1000 .
$$




\section{DATA AND RESULTS}

\section{Hydraulic Gradients-Bayou Creek}

The direction of hydraulic gradients (between piezometers and streams, wells and streams, and piezometers and wells) varied with location in the watersheds and with time. Except as noted below, monthly monitoring occurred when Bayou and Little Bayou Creeks were at or near baseflow. Rainfall was $\leq 20 \mathrm{~mm}$ during the two days preceding monitoring except for November 25-26 and December $17-19,1996$. Summaries of data for each creek are given starting at the study location farthest upstream and progressing downstream. Additional data can be found in Wallin (1998). Because differences in hydraulic head between paired wells usually were within surveying and measurement error $(\leq 0.04 \mathrm{~m})$, only data for the shallower well are referenced except as noted.

BB5 was located along Bayou Creek $\sim 950 \mathrm{~m}$ upstream of the first PGDP outfall. Piezometers and wells were installed in the terrace gravels, with the screened interval for BB5Z (110.4 to $111.1 \mathrm{~m}$ amsl) overlapping the perforated intervals for piezometers BB5B and BB5C. Stream stage ranged from 111.6 to $111.9 \mathrm{~m}$ amsl under baseflow conditions (Figure 7). Head in BB5C, the shallower of the two piezometers, was at stream stage (within error) throughout monitoring. In $\mathrm{BB} 5 \mathrm{~B}$, which was completed in an iron-oxide-cemented hardpan, head fluctuated below and above stream stage (within $0.8 \mathrm{~m}$ ), which suggests that BB5B did not equilibrate with stage changes as rapidly as BB5C. Head in BB5Z decreased steadily from $113.0 \mathrm{~m}$ amsl in January 1997 to $111.9 \mathrm{~m}$ amsl (0.1 m above stream stage) in October 1997. Head in BB5Y was less than in BB5Z (by as much as $0.1 \mathrm{~m}$ ) in January, April, and May 1997.

BB4 was located in an unnamed perennial stream $\sim 10 \mathrm{~m}$ upstream of its confluence with Bayou Creek, adjoining a closed sanitary landfill at the southwest corner of PGDP. As at BB5, piezometers BB4A and BB4B, which was destroyed during a flood, were installed in the terrace gravels. From July 1996 to May 1997, head in BB4A ranged from 0 to $0.4 \mathrm{~m}$ above stream stage, which in turn was 

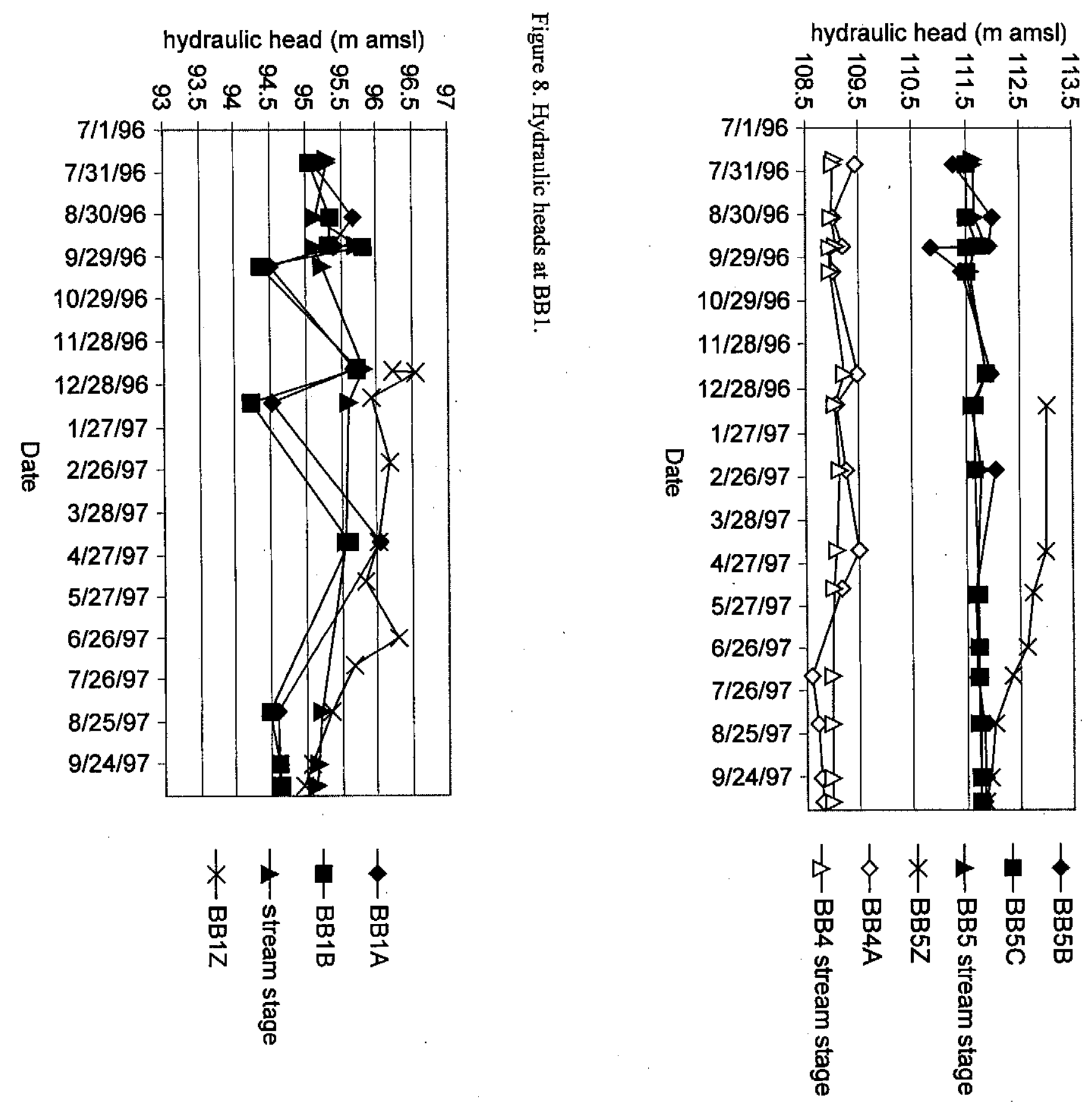

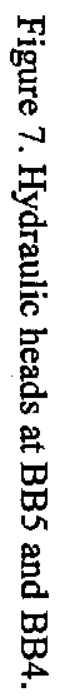


relatively constant (109.0 to $109.2 \mathrm{~m}$ amsl) (Figure 7). After May 1997, head in BB4A fell below stream stage by as much as $0.4 \mathrm{~m}$. Piezometers were installed in sandy shoals at BB3 (1.4 km downstream of BB4) and BB2 ( $2.3 \mathrm{~km}$ downstream of BB3). Except for BB2B on February 22, 1997, heads in those piezometers remained essentially at stream stage (within $0.05 \mathrm{~m}$ ) during the study. At BB3, only one stream-bank monitoring well (BB3Y, completed in sand overlying the RGA at $12.0 \mathrm{~m}$ depth) was installed. Heads in both BB3Y and RGA well MW 142, $50 \mathrm{~m}$ upstream of BB2, peaked following the March 1997 flood. In BB3Y, the maximum measured head (102.1 m on April 19, 1997) was below stream stage $(105.9 \mathrm{~m})$. The maximum measured head in MW 142 was $101.9 \mathrm{~m}$ on March 25, but stream stage was not measured then.

Two wells and two piezometers were installed at BB1, the farthest downstream cluster on Bayou Creek ( $\sim .8 \mathrm{~km}$ below BB2). Both wells were completed in sand overlying the RGA, whereas the piezometers were completed in a clayey stratum beneath the creek. The screened interval for well BB1Z ( 93.5 to $94.3 \mathrm{~m} \mathrm{amsl}$ ) overlapped the perforated interval for piezometer BB1B. Both piezometers were skipped in November 1996, February 1997, and May-July 1997 because of flooding or apparent stagnation (Figure 8), which may have resulted from slow equilibration of the piezometers following inundation. At other times except September 1 and 22, 1996 (when the stream was high because of rainfall the preceding day), and April 18, 1997, heads in the piezometers were below stream stage, which ranged from 95.1 to $95.8 \mathrm{~m}$ amsl. Head in $\mathrm{BB} 1 \mathrm{Z}$ remained above stream stage except for the last two months of the study.

\section{Hydraulic Gradients—Little Bayou Creek}

Along the east side of PGDP, Little Bayou Creek has a clayey bed and is narrow $(\sim 2.7 \mathrm{~m}$ wide at LB7). Therefore, piezometers were not installed and stream stage was not monitored at LB7. The measured head in UCRS well LB7Y, while always above the creek, declined steadily from $111.7 \mathrm{~m}$ amsl on May 19, 1997, to $110.1 \mathrm{~m}$ amsl on October 12, 1997. At LB4, $1.0 \mathrm{~km}$ downstream, the shallower 
piezometer (LB4A) was located in a sandy shoal, whereas LB4B was completed in an underlying clayey stratum. Head in LB4A fluctuated above and below stream stage (106.3 to $106.4 \mathrm{~m}$ amsl), but was within $0.1 \mathrm{~m}$ of stream stage from April through October 1997. In LB4B, head fluctuated over a broader range (as much as $1.2 \mathrm{~m}$ ), and the piezometer was stagnant on several occasions. In RGA well MW 191, located on the bank at LB4, the maximum hydraulic head was $101.5 \mathrm{~m}$ amsl on April 28. Piezometers were also installed in a sandy shoal at LB3, $\sim 3.2 \mathrm{~km}$ downstream of LB4. Heads in LB3A and LB3B fell below stream stage (99.4 to $99.6 \mathrm{~m} \mathrm{amsl}$ ) from October 1996 through January 1997 (Figure 9). Except for LB3B on May 15 and October 11, heads in piezometers at LB3 remained above or at stream stage from April through October 1997. In the adjoining RGA well MW 137, hydraulic head peaked at $101.4 \mathrm{~m}$ amsl on March 24 and remained above stream stage through June 24.

LB6 was located on a channelized reach $\sim 1.3 \mathrm{~km}$ downstream of LB3, opposite the southwest corner of a closed ash pond at the Shawnee Plant. Two wells were completed in sand above the RGA and two piezometers were driven into the relatively clayey stream bed. The top of the screened interval for well LB6Z (93.0 $\mathrm{m}$ amsl) is $1.7 \mathrm{~m}$ below the bottom of the perforated interval for LB6A, the deeper piezometer. Both wells flowed in April and June 1997. Head in LB6Z, while always above stream stage (95.7-95.8 $\mathrm{m}$ amsl), steadily decreased from $\geq 98.4 \mathrm{~m}$ amsl (top of casing) in June 1997 to $96.9 \mathrm{~m}$ amsl in October 1997 (Figure 9). Head in LB6Y was $0.1 \mathrm{~m}$ greater than in LB6Z in February 1997; at other times, differences in head between the wells were negligible. The piezometers were submerged or stagnant from November 1996 through February 1997. Otherwise, head in LB6A was always below stream stage, and head in LB6B was below stream stage except on August 18, September 25, and October 11, 1997. At LB2, $230 \mathrm{~m}$ downstream of LB6, piezometers completed in the stream bed (LB2D and LB2E) were typically stagnant. In LB2A, on the east bank adjacent to the closed ash pond, head was 0.2 to $0.4 \mathrm{~m}$ above stream level until May 1997, when the piezometer was destroyed by a flood. 
Figure 9. Hydraulic heads at LB3 and LB6.

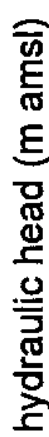

101.5
100.5
99.5
98.5
97.5
96.5
95.5
94.5

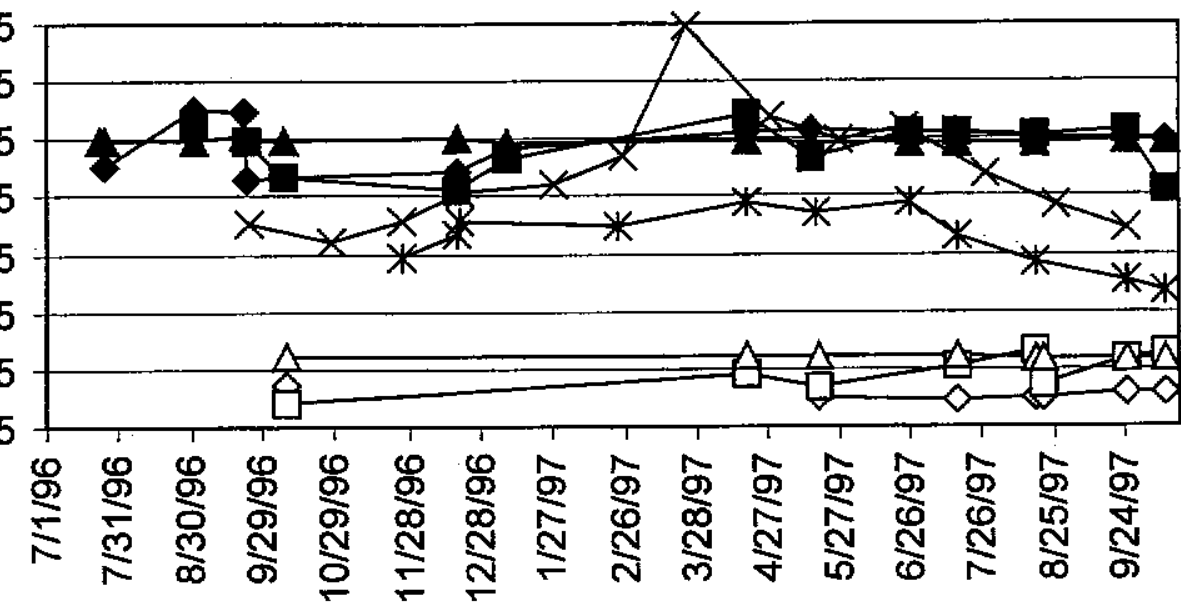

$\multimap$ LB3A

$\rightarrow$ LB3B

- LB3 stream stage

$\leftarrow$ MW 137

$\diamond$ LB6A

마- LB6B

$\triangle-$ LB6 stream stage

$\rightarrow$ LB6Z

Date

Figure 10. Hydraulic heads at LB1.

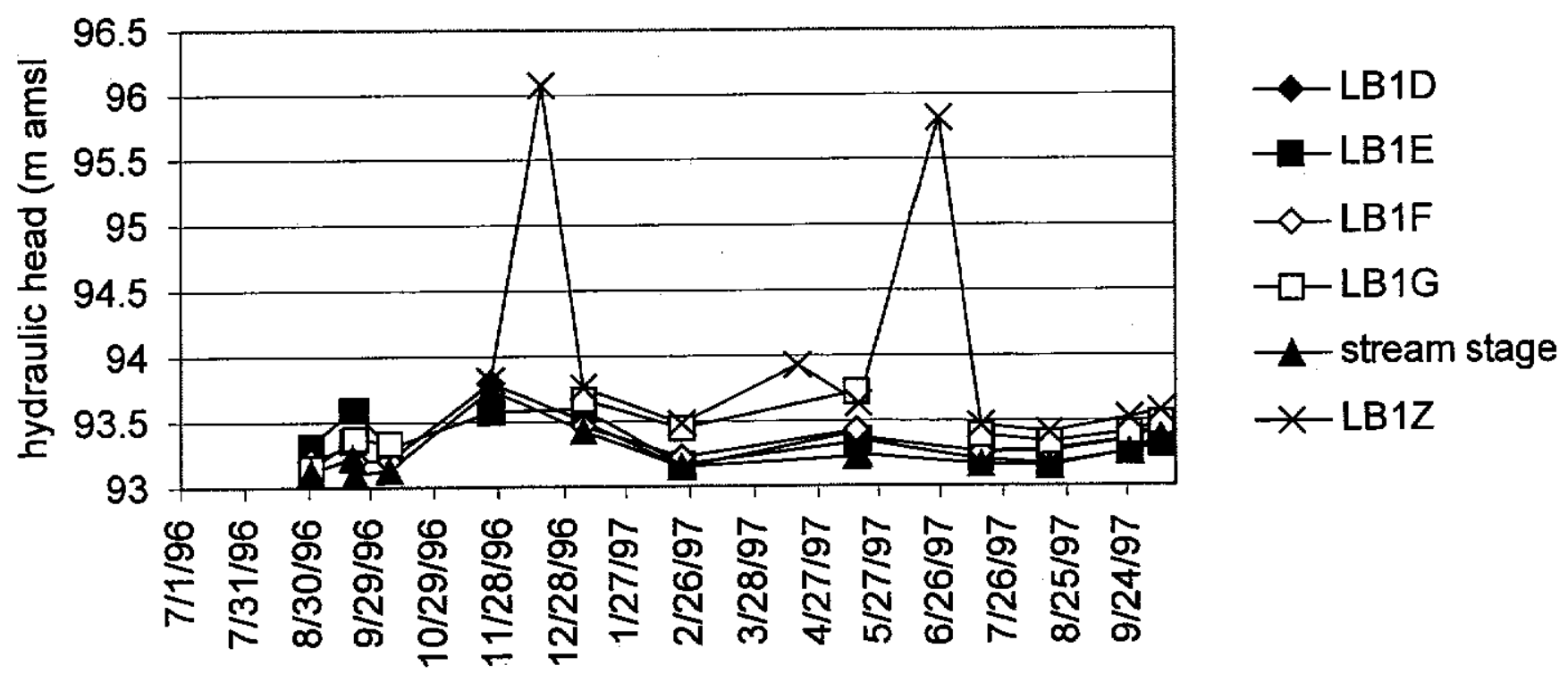

Date 
Between LB2 and LB1 ( $1.5 \mathrm{~km}$ downstream of LB2 and $\sim 130 \mathrm{~m}$ west of the current ash pond), Little Bayou Creek is incised into the RGA. At LB1, we installed two wells on the west bank, piezometers LB1D and LB1E along the west bank, and piezometers LB1F and LB1G in a gravel bar along the east bank. Both wells were completed in sand (possibly Ohio River alluvium) overlying the RGA. The screened interval for well $\operatorname{LB} 1 Z$ ( 91.3 to $92.1 \mathrm{~m}$ amsl) overlapped the perforated interval for piezometer LB1E (92.0 to $92.2 \mathrm{~m}$ amsl). Measured heads in all piezometers and wells were at or above stream stage throughout the study (Figure 10) except for LB1E on November 25, 1996 (following a storm), and October 10, 1997. Head in LB1G, the deeper of the two piezometers on the east bank, exceeded heads in the other piezometers from October 1996 through September 1997. Elevated heads in the wells occurred (and the piezometers were inaccessible) when the Ohio River backed up Little Bayou Creek in December 1996 and April and June 1997.

\section{Discharge Measurements}

We placed a seepage meter at least once at each piezometer cluster (except BB5, because of the hardpan in the stream bed) as well as in the bottoms downstream of BB1 and along the current ash pond between LB2 and LB1. After November 1996, seepage meters were placed only in areas of suspected ground-water discharge, where meters were usually left in the bed for less than an hour. Elsewhere, meters were left up to 31 hours. If left too long, the condom would fill to capacity, precluding a reliable measurement. Maximum values of $\mathrm{q}$ in reaches incised into the RGA or Ohio River alluvium (along the current ash pond, at LB1, and in the Bayou Creek bottoms) ranged from 0.38 to $1.1 \mathrm{~m} \mathrm{~d}^{-1}$ (Table 2).

Along other reaches, $\mathrm{q}$ was $\leq 0.028 \mathrm{~m} \mathrm{~d}^{-1}$ (the value measured $\sim 50 \mathrm{~m}$ upstream of the RGA contact in the Bayou Creek bottoms) except at LB6, where a value of $0.24 \mathrm{~m} \mathrm{~d}^{-1}$ was measured atop a sand boil on April 18, 1997. In comparison, $q$ was $0.92 \mathrm{~m} \mathrm{~d}^{-1}$ for a sand boil at LB1 in May. 
Table 2. Maximum specific discharge values measured by seepage meter.

Location

Bayou Creek bottoms

B81

BB2

BB3

BB4

LB1

LB1 boil

Ash pond

LB2

LB6

LB6 boil

LB3

LB4 $q$ maximum $\left(m d^{-1}\right)$

1.1

0.0098

0.014

0.0019

0.022

0.91

0.92

0.38

0.012

0.027

0.24

0.002

0.0072 
We gaged reaches of both creeks where the bed was relatively uniform. Because of morphologic changes (pooling behind beaver dams and logjams and the migration of shoals and bars) at some sites and our interest in delineating areas of ground-water discharge, we focused partway through the study on gaging along the channelized portion of Little Bayou Creek. At both LB2 and a location along the present ash pond (Figure 1), Q decreased to a minimum in October 1996, steadily increased to a peak in February 1997, then steadily decreased to another minimum in October 1997 (Figure 11). Other than two ephemeral tributaries, there are no surface-water inflows between these two sites, which are $\sim 760 \mathrm{~m}$ apart. We determined $q_{\mathrm{n}}$ values at either end of this segment of stream by gaging between LB6 and LB2 (195 m apart) and between transects 90 to $125 \mathrm{~m}$ apart along the ash pond. Maximum $\mathrm{q}_{\mathrm{n}}$ values $(0.43 \mathrm{~m}$ $\mathrm{d}^{-1}$ for LB6-LB2 and $1.2 \mathrm{~m} \mathrm{~d}^{-1}$ for the ash pond) occurred in May 1997 (Figure 12). At other times, $\mathrm{q}_{n}$ between LB6 and LB2 was $<0$, while $\mathrm{q}_{\mathrm{n}}$ along the ash-pond reach was near zero or negative $(\leq 0.13 \mathrm{~m}$ $\mathrm{d}^{-1}$ ) in September-October 1996 and July-September 1997.

\section{Temperatures}

Stream and bed temperatures typically tracked air temperatures, fluctuating seasonally from maxima in summer to minima in winter. As expected, fluctuations generally decreased with increasing depth at each site; for example, piezometer temperatures tended to be less than stream temperatures in summer and greater in winter (Figure 13). Temporal ranges in stream temperature varied from $23.8^{\circ} \mathrm{C}$ (BB1) to $28.3^{\circ} \mathrm{C}(\mathrm{BB} 2)$ along Bayou Creek (Table 3). Stream-temperature ranges along Little Bayou Creek progressively decreased downstream from $27.0^{\circ} \mathrm{C}$ at $\mathrm{LB} 3$ to $13.0^{\circ} \mathrm{C}$ at $\mathrm{LB} 1$. Piezometertemperature ranges were narrowest along Bayou Creek at BB1B $\left(17.8^{\circ} \mathrm{C}\right)$ and along Little Bayou at $\mathrm{LB} 1 \mathrm{G}\left(2.4^{\circ} \mathrm{C}\right)$. The range for each piezometer at $\mathrm{LB} 1$ was $\leq 7.4^{\circ} \mathrm{C}$, with those on the east bank (F and $\mathrm{G}$, adjoining the current ash pond) having narrower ranges and greater maximum values than those on the west bank (Figure 13). The range was narrower for the deeper piezometer in all pairs except at BB5 and 


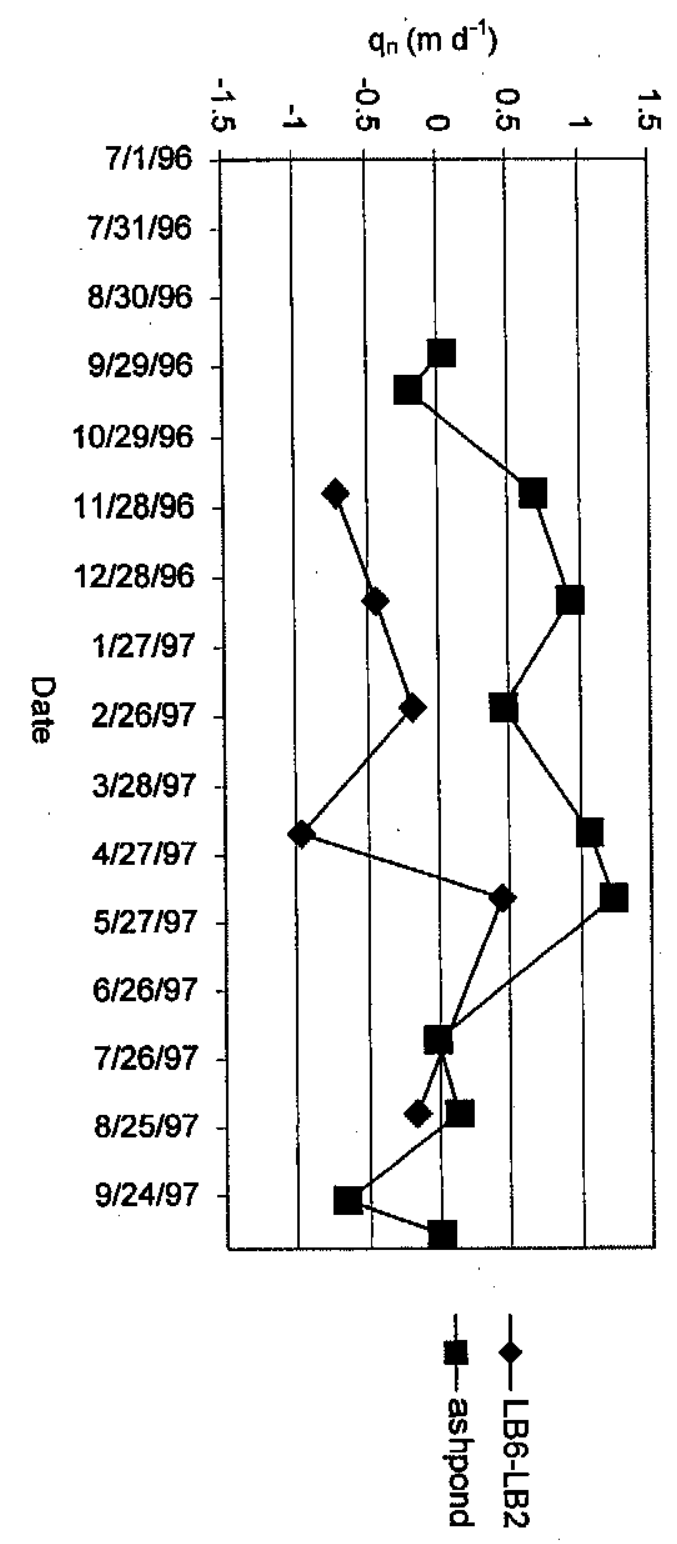

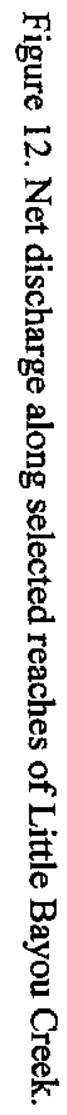

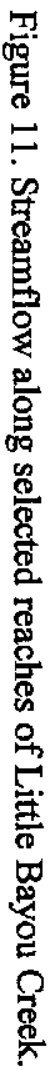


Figure 13. Air, stream, piezometer, and well temperatures at LB1.

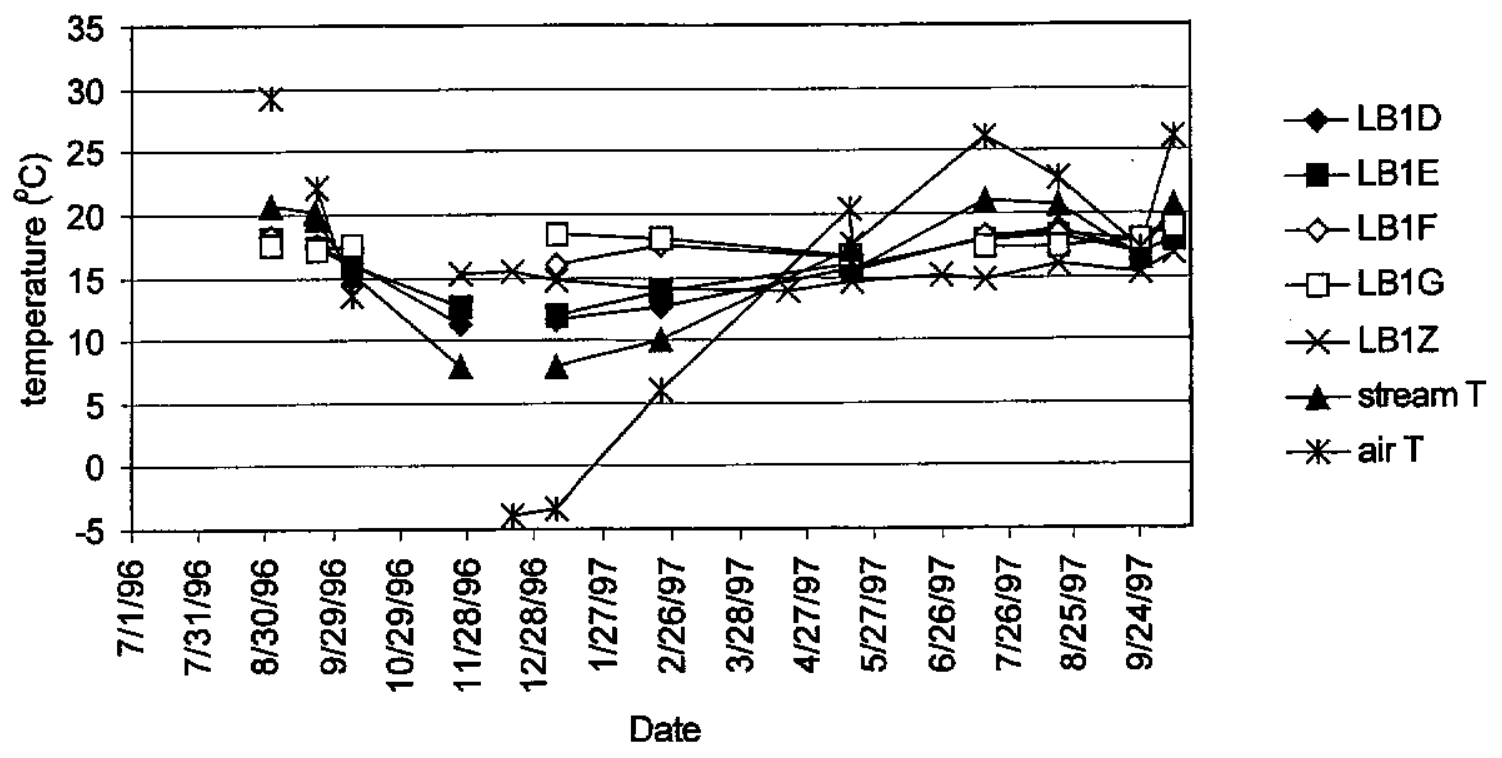

Figure 14. Bed temperatures along downstream reach of Little Bayou Creek with stream and air temperatures at LB1 for comparison.

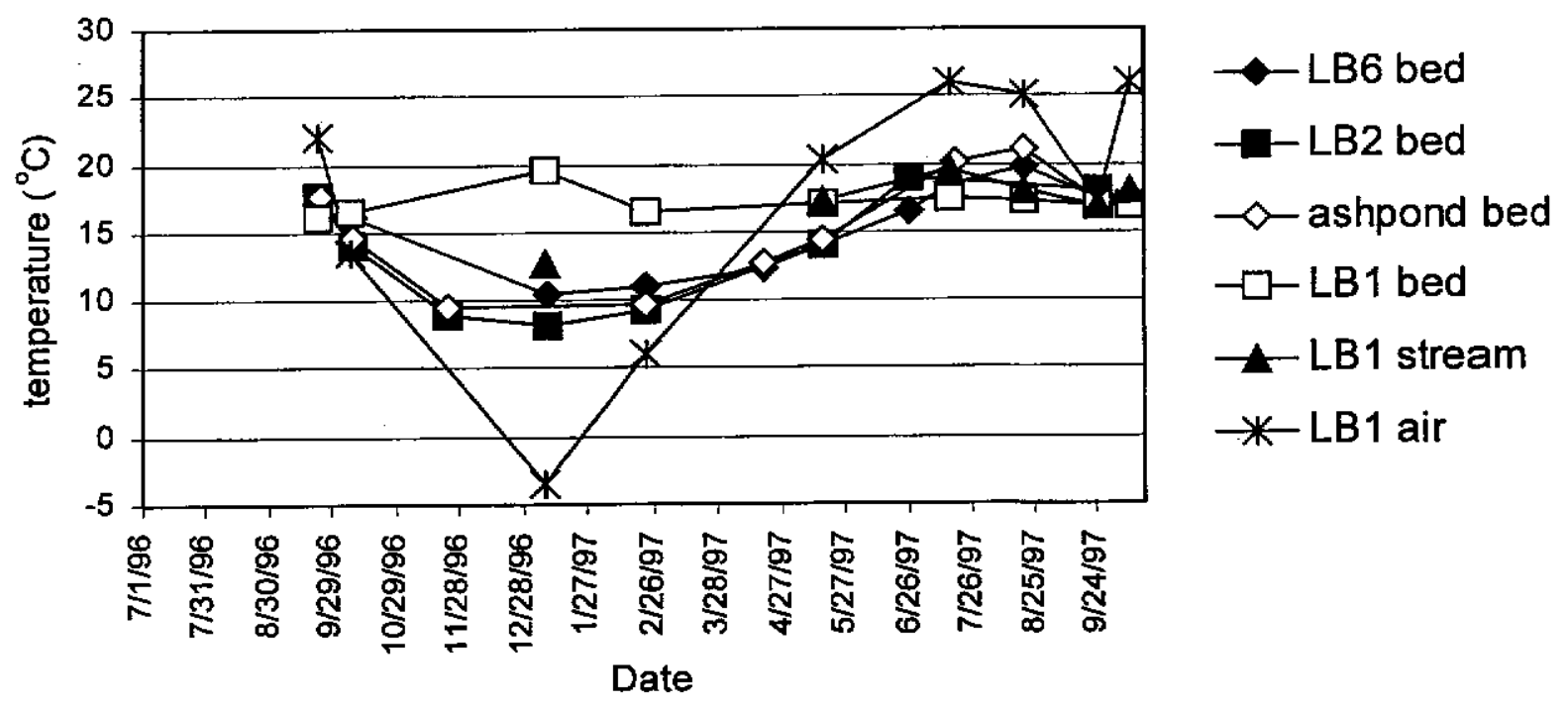


Table 3. Piezometer, well, bed, and stream temperatures.

\begin{tabular}{|c|c|c|c|}
\hline Location & $\operatorname{Min} . \mathrm{T}\left({ }^{\circ} \mathrm{C}\right)$ & $\operatorname{Max} . T\left({ }^{\circ} \mathrm{C}\right)$ & T range $\left({ }^{\circ} \mathrm{C}\right)$ \\
\hline BB1A & 5.7 & 25.1 & 19.4 \\
\hline $\mathrm{BB} 1 \mathrm{~B}$ & 6.2 & 24.0 & 17.8 \\
\hline BB1Y & 10.5 & 16.0 & 5.5 \\
\hline $\mathrm{BB} 1 \mathrm{Z}$ & 10.1 & 16.4 & 6.3 \\
\hline BB1 stream & 2.9 & 26.7 & 23.8 \\
\hline BB2A & 6.9 & 27.7 & 20.8 \\
\hline $\mathrm{BB} 2 \mathrm{~B}$ & 7.1 & 27.0 & 19.9 \\
\hline BB2 stream & 3.5 & 31.8 & 28.3 \\
\hline BB3A & 4.4 & 27.1 & 22.7 \\
\hline BB3B & 4.4 & 26.5 & 22.1 \\
\hline BB3Y & 14.1 & 15.5 & 1.4 \\
\hline BB3 stream & 3.5 & 31.5 & 28.0 \\
\hline BB4A & 5.1 & 28.4 & 23.3 \\
\hline BB4 stream & 2.8 & 29.7 & 26.9 \\
\hline BB5B & 1.0 & 24.1 & 23.1 \\
\hline BB5C & 3.7 & 24.1 & 20.4 \\
\hline BB5Y & 12.0 & 15.8 & 3.8 \\
\hline BB5Z & 11.7 & 16.2 & 4.5 \\
\hline BB5 stream & 1.4 & 28.9 & 27.5 \\
\hline LB1D & 11.3 & 18.7 & 7.4 \\
\hline LB1E & 11.9 & 18.3 & 6.4 \\
\hline LB1F & 15.9 & 19.5 & 3.6 \\
\hline LB1G & 16.6 & 19.0 & 2.4 \\
\hline LB1Y & 14.0 & 15.8 & 1.8 \\
\hline LB1Z & 13.8 & 16.8 & 3.0 \\
\hline LB1 bed (midstream) & 16.2 & 19.5 & 3.3 \\
\hline LB1 stream & 8.0 & 21.0 & 13.0 \\
\hline Ash-pond bed (midstream) & 9.4 & 21.1 & $\uparrow 1.7$ \\
\hline Ash-pond stream & 5.8 & 23.1 & 17.3 \\
\hline LB2D & 6.2 & 20.8 & 14.6 \\
\hline LB2E & 5.8 & 21.7 & 15.9 \\
\hline LB2 bed (midstream) & 9.7 & 21.2 & 11.5 \\
\hline LB2 stream & 3.2 & 23.8 & 20.6 \\
\hline LB6A & 9.3 & 19.6 & 10.3 \\
\hline LB6B & 9.5 & 19.8 & 10.3 \\
\hline LB6Y & 8.7 & 17.2 & 8.5 \\
\hline LB6Z & 8.4 & 17.2 & 8.8 \\
\hline LB6 bed (west bank) & 10.4 & 19.8 & 9.4 \\
\hline LB6 stream & 0.9 & 23.7 & 22.8 \\
\hline LB3A & 4.2 & 25.4 & 21.2 \\
\hline LB3B & 6.9 & 24.3 & 17.4 \\
\hline LB3 stream & 1.0 & 28.0 & 27.0 \\
\hline LB4A & 4.7 & 26.8 & 22.1 \\
\hline LB4B & 6.9 & 25.6 & 18.7 \\
\hline LB4 stream & 3.3 & 29.1 & 25.8 \\
\hline LB7Y & 14.3 & 16.1 & 1.8 \\
\hline
\end{tabular}


LB6 (excluding BB4, where one piezometer was washed away). Likewise, the range was narrower in the deeper well at locations with paired wells. Well-temperature ranges varied from $1.4^{\circ} \mathrm{C}$ for $\mathrm{BB} 3 \mathrm{Y}$ (minimum $14.1^{\circ} \mathrm{C}$, maximum $15.5^{\circ} \mathrm{C}$ ) to $8.8^{\circ} \mathrm{C}$ for $\mathrm{LB} 6 \mathrm{Z}$ (minimum $8.4^{\circ} \mathrm{C}$, maximum $17.2^{\circ} \mathrm{C}$ ).

Like seepage-meter placement and stream gaging, temperature probing was initially conducted at multiple locations in each watershed. We measured temperature at the surface of the bed or bank (if submerged) and at the maximum depth to which the probe could be pushed, which was limited by refusal in clayey and cobbly sediments and by the length of the probe in sandy and gravelly sediments. After October 1996, we focused on possible sites of ground-water discharge, including the Bayou Creek bottoms and Little Bayou Creek downstream of LB3. When the bottoms were accessible (September-November 1996 and July-October 1997), we probed at various points along an $500 \mathrm{~m}$ reach. Within $\sim 20 \mathrm{~m}$ downstream of the RGA contact, temperatures at depth decreased by 4.7 to $4.8^{\circ} \mathrm{C}$ (to $14.7^{\circ} \mathrm{C}$ in August 1997 and $14.4^{\circ} \mathrm{C}$ in October 1997). Where seeps were observed, bed and bank temperatures ranged from 14.3 to $16.5^{\circ} \mathrm{C}$, while temperatures at the base of the water column were as much as $24.4^{\circ} \mathrm{C}$.

Along Little Bayou, the temporal range in bed temperature increased slightly downstream from LB6 $\left(9.4^{\circ} \mathrm{C}\right.$ along the west bank) to $\mathrm{LB} 2$ and the ash-pond reach $\left(11.5\right.$ to $11.7^{\circ} \mathrm{C}$ at midstream $)$, then decreased to LB1 (3.3 ${ }^{\circ} \mathrm{C}$ at midstream) (Figure 14). From September 1996 through May 1997, we also probed at both piezometer nests at LB1. Except in September, temperatures at depth increased from the west bank through midstream to the east bank, where the maximum temperature $\left(21.2^{\circ} \mathrm{C}\right)$ was recorded in January 1997. In July 1998, we probed two sand boils in the bed and one spring on each bank along a reach extending from $\sim 200 \mathrm{~m}$ to $41 \mathrm{~m}$ upstream of LB6. Temperatures were 14.2 to $14.3^{\circ} \mathrm{C}$ at depth in the boils and 15.0 to $15.6^{\circ} \mathrm{C}$ at the mouths of the springs, while air temperature was $25.8^{\circ} \mathrm{C}$ and the stream temperature was $23.1^{\circ} \mathrm{C}$ at the downstream end of the reach. 


\section{Hydrochemical Parameters and Mixing Modeling}

Chloride and $\delta^{18} \mathrm{O}$ in stream water varied with both location and time, whereas values in ground water varied with location but were relatively invariant with time (Table 4). In stream water, $\mathrm{Cl}^{-}$ concentrations were always lowest at BB5 $\left(11.6\right.$ to $\left.18.5 \mathrm{mg} \mathrm{L}^{-1}\right)$, greatest at BB3 in May and October 1997 (60.6 to $79.0 \mathrm{mg} \mathrm{L}^{-1}$ ), and greatest at BB1 in August $1997\left(50.7 \mathrm{mg} \mathrm{L}^{-1}\right)$. Along Little Bayou Creek, $\mathrm{Cl}^{-}$was lowest at LB1 (except in January) and increased from LB7 to LB6. Trends in $\delta^{18} \mathrm{O}$ were similar to those of $\mathrm{Cl}^{-}$along Bayou Creek: $\delta^{18} \mathrm{O}$ was always lowest at BB5 $(-6.3$ to $-4.8 \%)$, highest in May and October at BB3 (-3.3\%), and highest in August at BB1 (-3.5\%). Along Little Bayou, $\delta^{18} \mathrm{O}$ was relatively invariant in January and May, but $\delta^{18} \mathrm{O}$ decreased downstream in August and October.

In ground water, $\mathrm{Cl}^{-}$concentrations varied by $\leq 2.2 \mathrm{mg} \mathrm{L}^{-1}$ in each well (Table 4). Average concentrations in ground water along Bayou Creek increased from $3.3 \mathrm{mg} \mathrm{L}^{-1}$ in BB5Y to $3.8 \mathrm{mg} \mathrm{L}^{-1}$ in $\mathrm{BB} 3 \mathrm{Y}$ and thence to $7.4 \mathrm{mg} \mathrm{L}^{-1}$ in $\mathrm{BB} 1 \mathrm{Y}$. Conversely, average concentrations in ground water along Little Bayou decreased from $61.0 \mathrm{mg} \mathrm{L}^{-1}$ in LB7Y to $33.4 \mathrm{mg} \mathrm{L}^{-1}$ in LB6Y and thence to $12.2 \mathrm{mg} \mathrm{L}^{-1}$ in LB1Y. Along Bayou Creek, $\mathrm{Cl}^{-}$was always lower in ground water than in stream water; along Little Bayou, $\mathrm{Cl}^{-}$was lower in stream water than in ground water at LB7 and (except for August 1997) at LB6. Except at BB5 and LB1 in January, ground water was always depleted in ${ }^{18} \mathrm{O}$ relative to stream water. Values of $\delta^{18} \mathrm{O}$ in ground water varied from -5.8 to $-6.5 \%$, with the most enriched values always occurring in LB1Y $(-5.8$ to $-6.0 \%)$. The temporal range in $\delta^{18} \mathrm{O}$ for any well was $\leq 0.4 \%$, with the range among wells at any time $\leq 0.5 \%$. In comparison, Sturchio et al. (1998) reported $\delta^{18} \mathrm{O}$ of -4.9 to $-5.8 \%$ for RGA and UCRS wells.

Among trace solutes, B was monitored at all sampling locations in both watersheds, while TCE and ${ }^{99} \mathrm{Tc}$ were measured in stream and ground water beginning in January 1997 at LB6, in May 1997 at LB1, and in August 1997 at LB7. Boron was detected consistently in stream water at LB1 (at 
Table 4. Solute and oxygen-18 concentrations in stream (S suffix) and well (Y suffix) water.

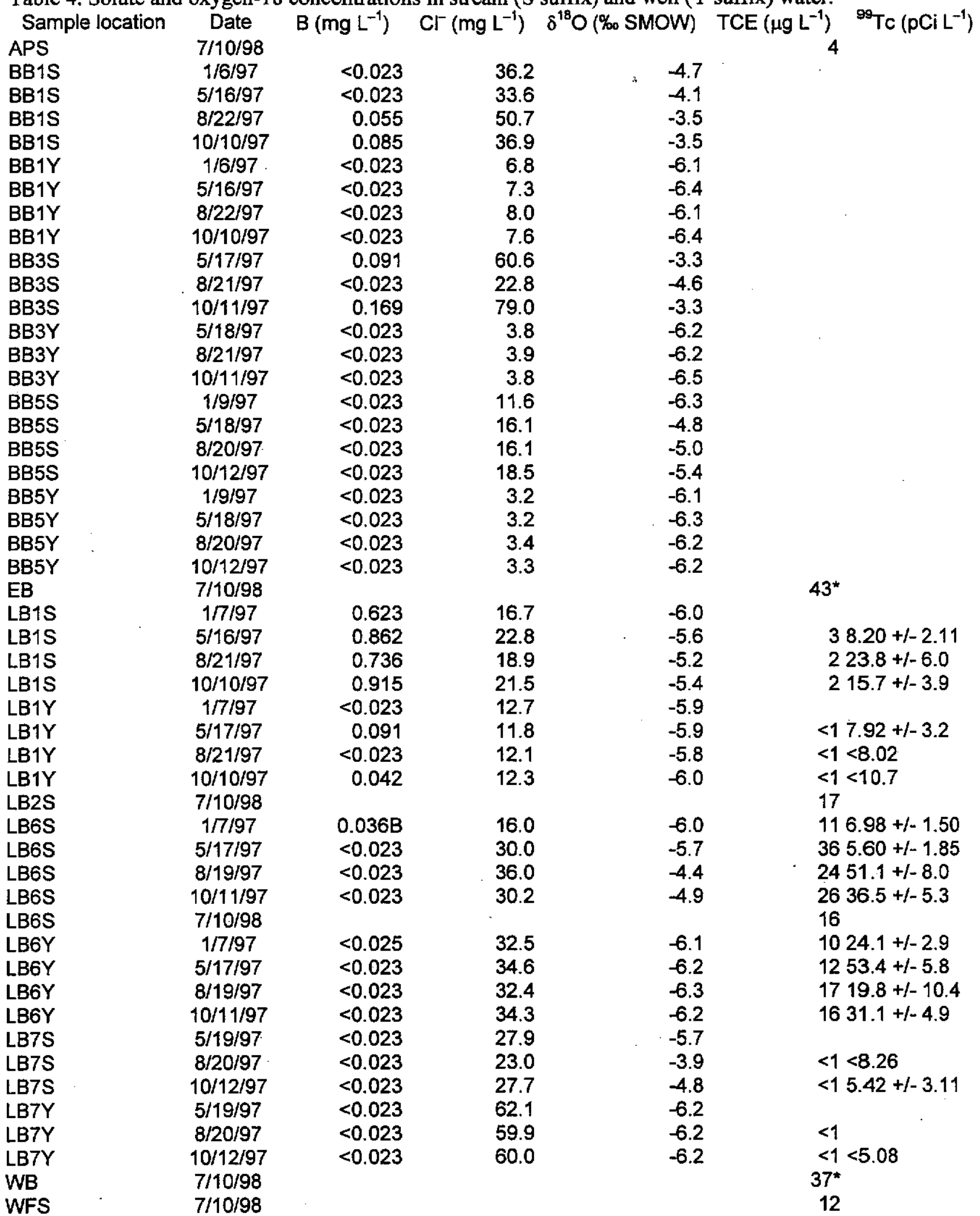

Notes: $\mathrm{B}$ flag $=$ detected in blank; * = sample diluted $5 x$ to fall within calibration range of GC.

$E B=$ east-bank spring and $W B=$ west-bank spring. 
concentrations of 0.623 to $0.915 \mathrm{mg} \mathrm{L}^{-1}$ ) and sporadically in well LB1Y and in stream water at BB3 and BB1 (at concentrations $\leq 0.169 \mathrm{mg} \mathrm{L}^{-1}$ ). At other times and locations, B concentrations were below detection limit $\left(0.023\right.$ to $\left.0.026 \mathrm{mg} \mathrm{L}^{-1}\right)$ or measured both in the sample and a blank (for stream water at LB6 in January 1997). Sampling for TCE and ${ }^{99} \mathrm{Tc}$ focused initially on LB6 because of its proximity to the Northwest Plume. In stream water, TCE concentrations were below detection limit $\left(<1 \mu \mathrm{g} \mathrm{L}^{-1}\right)$ at LB7, 11 to $33 \mu \mathrm{g} \mathrm{L}^{-1}$ at LB6, and 2 to $3 \mu \mathrm{g} \mathrm{L}^{-1}$ at LB1 (Table 4). Technetium-99 activities in stream water were $<8.26 \mathrm{pCi} \mathrm{L}^{-1}$ at LB7, 5.60 to $51.1 \mathrm{pCi} \mathrm{L}^{-1}$ at $\mathrm{LB} 6$, and 8.20 to $23.8 \mathrm{pCi} \mathrm{L}^{-1}$ at LB1. Among the wells sampled, only LB6Y had detectable TCE $\left(10\right.$ to $\left.17 \mu \mathrm{g} \mathrm{L}^{-1}\right)$ and consistently detectable ${ }^{99} \mathrm{Tc}$ (19.9 to $53.4 \mathrm{pCi} \mathrm{L}^{-1}$ ). TCE was always higher in stream water than in ground water at LB6 and LB1. However, TCE concentrations were highest in the two springs sampled upstream of LB6 in July 1998 (37 to $43 \mu \mathrm{g} \mathrm{L}^{-1}$ in diluted samples).

We used $\mathrm{Cl}^{-}$and $\delta^{18} \mathrm{O}$ as mixing parameters in the program NETPATH (Plummer et al., 1994) to assess infiltration from Bayou Creek between BB5 and BB1 and ground-water discharge to Little Bayou Creek between LB7 and LB6. Following the findings of Evaldi and McClain (1989), models included (1) BB5Y ground water + BB5 or BB3 stream water $\rightarrow$ BB3Y ground water, (2) BB3Y ground water $\div$ BB3 or BB1 stream water $\rightarrow$ BB1Y ground water, and (3) LB7 stream water + LB6Y ground water $\rightarrow$ LB6 stream water. We did not attempt to quantify mixing downstream of LB6 because of a paucity of hydrochemical data for the TVA ash ponds. Because neither BB3 nor LB7 was sampled in January 1997, we calculated mixing percentages for May, August, and October 1997 (Table 5). Agreement between $\mathrm{Cl}^{-}$derived percentages and $\delta^{18} \mathrm{O}$-derived percentages was better for Bayou Creek than for Little Bayou. Model 1 suggests that 0 to $7 \%$ (for $\delta^{18} \mathrm{O}$ ) or 1 to $5 \%\left(\right.$ for $\mathrm{Cl}^{-}$) of ground water in $\mathrm{BB} 3 \mathrm{Y}$ originated as stream water between BB5 and BB3. Model 2 suggests that 3 to $6 \%\left(\right.$ for $\delta^{18} \mathrm{O}$ ) or 5 to $22 \%$ (for $\mathrm{Cl}^{-}$) of ground water in BB1Y originated as stream water between $\mathrm{BB} 3$ and $\mathrm{BB} 1$. Model 3 indicates that 0 to $21 \%$ (for $\delta^{18} \mathrm{O}$ ) or 31 to $38 \%$ (for $\mathrm{Cl}^{-}$) of stream water at LB6 was contributed by ground water 
Table 5. Models of ground-water/stream-water mixing along Bayou and Little Bayou Creeks.

Date Model

May 1997 BB5Y + BB5S $=$ BB3Y

$B B 5 Y+B B 3 S=B B 3 Y$

$B B 3 Y+B B 3 S=B B 1 Y$

$B B 3 Y+B B 1 S=B B 1 Y$

LB7S + LB6Y $=$ LB6S

Aug. 1997 BB5Y + BB5S $=B B 3 Y$

$B B 5 Y+B B 3 S=B B 3 Y$

$B B 3 Y+B B 3 S=B B 1 Y$

$B B 3 Y+B B 1 S=B B 1 Y$

$L B 7 S+L B 6 Y=L B 6 S$

Oct. 1997 BB5Y + BB5S $=B B 3 Y$

$B B 5 Y+B B 3 S=B B 3 Y$

$B B 3 Y+B B 3 S=B B 1 Y$

$B B 3 Y+B B 1 S=B B 1 Y$

$\mathrm{LB} 7 \mathrm{~S}+\mathrm{LB} 6 \mathrm{Y}=\mathrm{LB} 6 \mathrm{~S}$
Parameter End member $1 \%$ End member $2 \%$

$\begin{array}{rr}95 & 5 \\ 93 & 7 \\ 99 & 1 \\ 97 & 3 \\ 94 & 6 \\ \text { N/A } & \text { N/A } \\ 88 & 12 \\ \text { N/A } & \text { N/A } \\ 69 & 31 \\ 100 & 0\end{array}$

$96 \quad 4$

$100 \quad 0$

$97 \quad 3$

$100 \quad 0$

$78 \quad 22$

$94 \quad 6$

$91 \quad 9$

$96 \quad 4$

N/A N/A

$79 \quad 21$

$97 \quad 3$

N/A N/A

$99 \quad 1$

N/A N/A

$95 \quad 5$

$97 \quad 3$

$89 \quad 11$

$97 \quad 3$

$62 \quad 38$

$93 \quad 7$ 
resembling LB6Y in composition. Although mixing percentages varied with time in each case, a systematic trend is apparent only for the mixture BB5Y ground water + BB5 stream water $\rightarrow$ BB3Y ground water, in which the percentage of infiltrating stream water decreased from May through October. No solution could be obtained for $\delta^{18} \mathrm{O}$ for model 1 in October, for $\delta^{18} \mathrm{O}$ for model 2 in May, or for $\mathrm{Cl}^{-}$for model 3 in August. 


\section{Discussion}

\section{Losing or no-net-discharge reaches of creeks}

During baseflow, losing conditions occurred between BB5 and the bottoms (except sometimes BB4) on Bayou Creek, while losing or no-net-discharge conditions occurred between LB7 and LB3 on Little Bayou Creek, as observed by Evaldi and McClain (1989) from gaging data. Our evidence includes downward or near-zero hydraulic gradients between the stream and piezometers and, along Bayou Creek, mixing calculations using $\mathrm{Cl}^{-}$and $\delta^{18} \mathrm{O}$. These lines of evidence coincide with maximum $\mathrm{q}$ values $<0.028$ $\mathrm{m} \mathrm{d}^{-1}$, stream-temperature ranges $\geq 23.8^{\circ} \mathrm{C}$, and piezometer-temperature ranges $\geq 17.8^{\circ} \mathrm{C}$. Hydraulic gradients and small, positive values of q suggest some stream-water flow within the bed. Mixing calculations support the hypothesis of Clausen et al. (1992) that infiltration occurs along Bayou Creek in particular where stream channel deposits extend from the terrace gravels into the RGA (between BB5 and BB3). Infiltration is probably augmented by outfall discharges along this reach, which adjoins suspected source areas of the Northwest Plume (Clausen et al., 1995).

Monitoring wells at BB5 displayed an upward hydraulic gradient relative to Bayou Creek, but piezometers did not, probably because the terrace gravels were confined by the hardpan. Because Bayou Creek is perennial at BB5, diffuse ground-water discharge probably occurs upstream. Evidence of seepage at BB5 is limited by the shallowness of the creek, which precluded gaging at baseflow; the hardpan, which precluded temperature probing and installation of seepage meters; and the lack of upstream hydrochemical data. At BB4, discharge to Bayou Creek and its unnamed tributary was evident both from the upward hydraulic gradient between BB4A and the tributary during the first ten months of the study and from iron oxyhydroxide flocs in the stream bed adjacent to the closed landfill. Phillips and Douthitt (1993) suggested that the ineffectiveness of the clay cap on the landfill allowed infiltration of precipitation, leading to leachate generation and water-table mounding, which was probably accentuated 
by above-average precipitation during 1996-1997. However, the low values of $q\left(\leq 0.022 \mathrm{~m} \mathrm{~d}^{-1}\right)$ and broad ranges of stream temperatures $\left(26.9^{\circ} \mathrm{C}\right)$ and piezometer temperatures $\left(23.3^{\circ} \mathrm{C}\right)$ indicate that ground-water circulation at BB4 was localized. At BB1, heads in the wells were above stream stage until the last two months of the study, while heads in the piezometers were typically below stream stage. As at BB5, hydraulic gradients suggest convergent flow in substream sediments, with upward flow under confined conditions in the lower Continental Deposits and infiltration from the creek. Ranges of stream and piezometer temperatures, $q$ values, and mixing percentages at $\mathrm{BB} 1$ were similar to those at upstream sites that exhibited losing conditions.

Assessing seepage to and from Little Bayou Creek at LB7 is problematic for some of the same reasons as at BB5. The relatively narrow, shallow, and clayey stream bed precluded use of piezometers and seepage meters and limited gaging and temperature probing. In addition, we did not collect upstream hydrochemical data, and a meaningful range in stream temperatures cannot be calculated because of a lack of measurements between October 9, 1996, and May 19, 1997. However, differences of 9.4 to 15.1 ${ }^{\circ} \mathrm{C}$ between ground-water and stream temperatures from May through October 1997 suggest a lack of ground-water discharge at LB7, consistent with topographic maps that show Little Bayou Creek upstream of LB3 as ephemeral prior to construction of PGDP (i.e., prior to outfall discharges). Artesian conditions in LB7Y, as at BB1, probably reflect aquifer confinement. Hydraulic heads in piezometers at LB4, which were occasionally above stream stage, do not indicate ground-water discharge, given the broad ranges of stream and piezometer temperatures, minimal seepage fluxes, and the downward hydraulic gradient from the creek to the adjoining well MW 191. Results are ambiguous at LB3: hydraulic heads were above stream stage in both piezometer LB3A and well MW 137 from April through June 1997, during which time seepage was not measured. 


\section{Gaining reaches of creeks}

Gaining conditions occur in the bottoms on Bayou Creek, in addition to the reach along BB4, and downstream of LB3 on Little Bayou Creek. Evidence of ground-water discharge includes observations of bed and bank seeps and, for Little Bayou, upward hydraulic gradients in piezometers and wells and mixing calculations using $\mathrm{Cl}^{-}$and $\delta^{18} \mathrm{O}$. These coincided with maximum $\mathrm{q}$ and $\mathrm{q}_{\mathrm{n}}$ values $\geq 0.24 \mathrm{~m} \mathrm{~d}^{-1}$ and (along Little Bayou) temporal temperature ranges $\leq 22.8^{\circ} \mathrm{C}$ for the stream, $\leq 15.9^{\circ} \mathrm{C}$ for piezometers, and $\leq 11.7^{\circ} \mathrm{C}$ for the bed. Discharge was marked by bed and bank temperatures as much as $9.8^{\circ} \mathrm{C}$ cooler than stream temperatures in summer and early autumn. Except at BB4, discharge occurs where the creeks are incised into the RGA, relatively coarse strata within the UCRS, or Ohio River alluvium, as indicated by stream-bed and bank lithologies changing from silt and sand to gravel and cobbles. Along Little Bayou Creek downstream of LB2, seepage occurs both from the RGA and from one or more ash ponds, as indicated at LB1 by the upward hydraulic gradient on both banks and by higher piezometer and bed temperatures on the east bank from October 1996 through May 1997. Boron concentrations in stream water at LB1 also indicate ash-pond seepage.

Although Evaldi and McClain (1989) located the transition from no-net-discharge to gaining conditions between LB3 and LB6, and mixing calculations indicate discharge upstream of LB6, evidence of gaining conditions between LB6 and LB2 is equivocal. Seeps along the east bank of Little Bayou Creek and upward hydraulic gradients in piezometer LB2A indicate seepage from the closed ash pond. Heads in wells at LB6 were always above stream stage, which indicates an upward hydraulic gradient from the RGA. However, heads in piezometers at LB6 were typically below stream stage, $q$ values measured with seepage meters were $\leq 0.027 \mathrm{~m} \mathrm{~d}^{-1}$ except in April, and $\mathrm{q}_{\mathrm{n}}$ values were $<0$ except in May. Bed-temperature ranges at LB6 were narrower and stream-temperature ranges were broader than those measured along the ash-pond reach downstream. These results suggest that (1) ash-pond seepage between LB6 and LB2 is volumetrically insignificant and (2) as at BB1, there is a downward hydraulic gradient 
from the stream and convergent flow within or beneath the bed except after Ohio River flooding. We did not measure seepage between LB3 and LB6, but within $200 \mathrm{~m}$ upstream of LB6, the bed becomes sandy to gravelly, and springs and boils occur along both banks. The upstream lithology, the spring and boil temperatures measured in August 1989 (Evaldi and McClain, 1989) and July 1998, and the lack of B in stream water at LB6 indicate that ground water discharges upstream of LB6 from the RGA and not the closed ash pond.

Temporal variability in seepage

Fluctuations in the magnitude and direction of hydraulic gradients, in values of $Q_{s}$ and $q_{n}$, and in mixing percentages indicate temporal variability in seepage along the creeks. Although monitoring was usually conducted during baseflow, some head fluctuations in piezometers completed in clay or cemented gravels may have resulted from slow re-equilibration following storms. Longer-term variability in seepage was associated with seasonal dry and wet periods and Ohio River flooding. During summer and early autumn, when evapotranspiration exceeded precipitation, stream flow was relatively low $\left(Q_{s}<4000\right.$ $\mathrm{m}^{3} \mathrm{~d}^{-1}$ and $\mathrm{q}_{\mathrm{n}} \leq 0.15 \mathrm{~m} \mathrm{~d}^{-1}$ ) along Little Bayou Creek between LB6 and the present ash pond. Mixing calculations suggest that the amount of infiltration from Bayou Creek upstream of the outfalls decreased from May through October 1997. From June through October 1997, heads declined in all our wells except at LB1. Rainfall from June 1 through October $12(363 \mathrm{~mm})$ was below normal $(417 \mathrm{~mm})$, which may explain why the hydraulic gradient between piezometer BB4B and the unnamed tributary to Bayou Creek became downward from July through October 1997 after having been upward or lateral from July 1996 through May 1997. Clausen et al. (1992) previously observed gradient reversals (upward in January-August 1991, then downward until December 1991) in paired RGA and UCRS wells $\sim 1.2 \mathrm{~km}$ from the river. 
Data from Little Bayou Creek indicate that baseflow seepage was highest from late autumn through spring. Values of $\mathrm{q}_{\mathrm{n}}$ were $\geq 0.45 \mathrm{~m} \mathrm{~d}^{-1}$ along the current ash pond from November 1996 through May 1997, while $Q_{s}$ values at LB2 and along the ash pond were $>4000 \mathrm{~m}^{3} \mathrm{~d}^{-1}$ from January through May 1997. Flooding of the Ohio River led initially to increased hydraulic heads in stream-side wells (e.g., at LB1 and BB1 in December 1996 and June 1997) as the creeks backed up. Gradient reversals following spring 1997 floods resulted in lateral flow away from the river and upward flow at LB3 through June. Ephemeral sand boils at LB6 and LB1 in April and May and $\mathrm{q}_{\mathrm{n}}$ maxima at LB6 and along the ash pond in May suggest temporary increases in discharge to Little Bayou Creek following flooding.

\section{Variability in hydrochemical parameters}

Spatial variability in hydrochemical parameters reflects various natural and anthropogenic sources of water and solutes, which are only partly delineated by mixing models. Upstream of the outfalls, Bayou Creek baseflow is sustained by ground-water discharge. Chloride and $\delta^{18} \mathrm{O}$ data suggest that BB5 stream water consists of partly evaporated baseflow (assuming that data from BB5Y represent the composition of baseflow) (Table 6). Increased $\mathrm{Cl}^{-}$and $\delta^{18} \mathrm{O}$ in stream water at $\mathrm{BB} 3$ are associated with outfall discharges. Decreases in stream-water $\mathrm{Cl}^{-}$between BB3 and BB1 in May and October 1997 may reflect dilution by tributaries to Bayou Creek, but the reason for the increase in $\mathrm{Cl}^{-}$along this reach in August is unclear.

In May and October, $\mathrm{Cl}^{-}$and $\delta^{18} \mathrm{O}$ in stream water at $\mathrm{LB} 7$ were less than at $\mathrm{BB}$, which indicates that the composition of outfall discharges to the two creeks differed. Elevated $\mathrm{Cl}^{-}$concentrations and the lack of TCE and ${ }^{99} \mathrm{Tc}$ in ground water at LB7 suggest an anthropogenic source of $\mathrm{Cl}^{-}$cross-gradient to the Northeast Plume at PGDP. Between LB7 and LB6, increases in $\mathrm{Cl}^{-}$, TCE, and ${ }^{99} \mathrm{Tc}$ in stream water are consistent with seepage from the Northwest Plume and possibly the Offsite ${ }^{99}$ Tc Plume. Between LB6 
Table 6. Concentration factors for evaporation of BB5Y ground water to yield BB5 surface water.

\begin{tabular}{lrr} 
Date & Parameter & \multicolumn{2}{c}{ Evaporation factor } \\
Jan. 1997 & $\mathrm{Cl}$ & 3.6 \\
& $\delta^{18} \mathrm{O}$ & 1.0 \\
May 1997 & $\mathrm{Cl}$ & 5.0 \\
& $\delta^{18} \mathrm{O}$ & 1.3 \\
Aug. 1997 & $\mathrm{Cl}$ & 4.7 \\
& $\delta^{18} \mathrm{O}$ & 1.2 \\
Oct. 1997 & $\mathrm{Cl}$ & 5.6 \\
& $\delta^{18} \mathrm{O}$ & 1.2
\end{tabular}


and $\mathrm{LB} 1$, decreases in $\mathrm{Cl}^{-}, \mathrm{TCE}$, and ${ }^{99} \mathrm{Tc}$ and the increase in $\mathrm{B}$ indicate dilution of contaminants in stream water by discharge from the RGA and the ash ponds. Decreases in $\delta^{18} \mathrm{O}$ of stream water between LB7 and LB1 in August and October 1997 and the relatively narrow and depleted range of $\delta^{18} \mathrm{O}$ in stream water at LB1 $(-5.2$ to $-6.0 \%)$ are also consistent with ground-water discharge. 


\section{SUMMARY AND CONCLUSIONS}

Using hydraulic, thermal, and hydrochemical techniques, we delineated spatial and temporal variability in seepage along first- and second-order tributaries of the Ohio River between July 1996 and July 1998. Monitoring extended farther upstream and downstream than in previous studies of these tributaries (e.g., Evaldi and McClain, 1989). During baseflow along Bayou Creek, losing conditions occurred between $\sim 9.3$ and $1.2 \mathrm{~km}$ upstream of the mouth. Gaining conditions occurred between the headwaters and a point $\sim 9.3 \mathrm{~km}$ upstream of the mouth, along the closed landfill $\sim 7.8 \mathrm{~km}$ upstream of the mouth, and in the bottoms within $\sim 1.2 \mathrm{~km}$ of the mouth. Losing or no-net-discharge conditions occurred along Little Bayou Creek from its headwaters to a point $\sim 4.0 \mathrm{~km}$ upstream of the mouth, while gaining conditions tended to occur downstream of that point. However, along an $\sim 280-\mathrm{m}$ segment of this downstream reach, infiltration from the creek and upward flow from the underlying aquifer was evident.

Such convergent flow was also evident at the farthest upstream and downstream monitoring locations on Bayou Creek. Temporary changes in seepage rates and reversals in seepage directions occurred over timescales of weeks to months, coinciding with dry periods in summer and early autumn and following Ohio River flooding in spring.

Evidence of losing or no-net-discharge conditions included downward or lateral hydraulic gradients; minimal q values (indicative of stream-water flow through the bed); and relatively broad annual ranges of stream and piezometer temperatures. Gaining conditions were evidenced by upward hydraulic gradients within the bed; larger $q$ and $q_{n}$ values; relatively narrow ranges of stream, piezometer, and bed temperatures; relatively cool bed and bank temperatures in summer and early autumn; detections of trace solutes in stream water; and observations of springs, boils, and seeps. Mixing models utilizing $\mathrm{Cl}^{-}$and $\delta^{18} \mathrm{O}$ supported inferences of losing and gaining conditions. All lines of evidence for gaining conditions occurred where Little Bayou Creek is incised into relatively coarse sediments in the Ohio River flood plain. Where Bayou Creek is incised into the terrace gravels, upward hydraulic gradients and seeps 
occurred along the closed landfill and probably upstream of BB5. However, stream- and piezometertemperature ranges were relatively broad and (along the landfill) $q$ values were relatively small, indicating diffuse discharge from local ground-water flow systems.

The combination of monitoring techniques used in this study overcame some of the limitations of individual techniques. Water-level measurements in stream-bed piezometers and stream-side wells helped to differentiate between hydraulic gradients within the bed and gradients toward or away from the stream. However, measurements in piezometers were limited by submergence and by slow reequilibration where the bed is clayey or indurated. Seepage meters and stream gaging allowed us to measure specific discharge over areas $<10^{-2} \mathrm{~m}^{2}$ and $>10^{2} \mathrm{~m}^{2}$, respectively. Seepage meters were especially useful for sand boils and along sinuous reaches with irregular bed topography (e.g., the Bayou Creek bottoms), which limits the accuracy of gaging (Rantz et al., 1982). In addition, discharge measurements obtained by gaging do not account for flow within the bed (Evaldi and McClain, 1989). Temperature probing worked well for delineating regional ground-water discharge along reaches without piezometers or wells. Like piezometers and seepage meters, temperature probes were most useful in sandy to gravelly sediments. Relatively broad temperature ranges in wells with shallow water levels, such as LB6Z, suggest radiant heating and cooling, which may have also affected temperature measurements in piezometers. Streamtemperature ranges can supplement other data in delineating gaining reaches, but, as suggested by White et al. (1987), they do not clearly indicate where ground water upwells beneath a losing reach. Lastly, mixing models require the simplifying assumptions that initial and final waters fall along a flowpath and that all end members are represented (Plummer et al., 1994). Ground-water flow from BB5 to BB3 is reasonable, but we assume that BB3 is a surrogate for ground water upgradient of BB1 (in the RGA west of Bayou Creek).

Our findings confirm that seepage along tributaries can affect contaminant transport in riverine watersheds. Infiltration along Bayou Creek, which is probably augmented by outfalls, may help to mobilize contaminants beneath the northwest corner of PGDP. Migration of the Northwest Plume toward the Ohio River is limited by discharge to Little Bayou Creek. Downstream dilution by uncontaminated 
ground water reduces concentrations of TCE and ${ }^{99} \mathrm{Tc}$ in Little Bayou Creek. Although ${ }^{99} \mathrm{Tc}$ data are ambiguous, increased TCE concentrations in Little Bayou Creek in May 1997 suggest that flooding may have shifted the position of the Northwest Plume and discharge of contaminated ground water to the stream. We are further examining seasonal variability in contaminant concentrations and processes other than dilution (e.g., biodegradation, sorption, and volatilization) that may attenuate contaminants in the discharge zone. We anticipate that our findings will pertain to other industrialized, riverine watersheds in the Gulf and Atlantic Coastal Plains. 


\section{REFERENCES}

Böhlke, J.K., and J.M. Denver. 1995. Combined use of groundwater dating, chemical, and isotopic analyses to resolve the history and fate of nitrate contamination in two agricultural watersheds, Atlantic coastal plain, Maryland. Water Resources Research 31, no. 9: 2319-2339.

CH2M Hill. 1991. Results of the site investigation, Phase I, at the Paducah Gaseous Diffusion Plant, Paducah, Kentucky, report KY/ER-4, prepared for the U.S. Department of Energy under subcontract to DOE contract DE-AC05-76OR00001. Oak Ridge, Tennessee: CH2M Hill.

CH2M Hill: 1992. Results of the site investigation, Phase II, at the Paducah Gaseous Diffusion Plant, Paducah, Kentucky, report KY/SUB/13B-97777C P-03/1991/1, prepared for the U.S. Department of Energy under subcontract to DOE contract DE-AC05-76OR00001. Oak Ridge, Tennessee: CH2M Hill.

Clausen, J.L., J.W. Douthitt, K.R. Davis, and B.E. Phillips. 1992. Report of the Paducah Gaseous Diffusion Plant groundwater investigation phase III, report KY/E-150, prepared for the U.S. Department of Energy under subcontract to DOE contract DE-AC05-760R00001. Kevil, Kentucky: Martin Marietta Energy Systems.

Clausen, J.L., J. Zutman, D.A. Pickering, and N. Farrow. 1995. Final report on drive-point profiling of the Northwest Plume and analysis of related data, report KY/ER-66, prepared for the U.S. Department of Energy under subcontract to DOE contract DE-AC05-76OR00001. Kevil, Kentucky: Martin Marietta Energy Systems.

Constantz, J. 1998. Interaction between stream temperature, streamflow, and groundwater exchanges in alpine streams. Water Resources Research 34, no. 7: 1609-1615.

Cooper, H.H., Jr., and M.I. Rorabaugh. 1963. Changes in ground-water movement and bank storage caused by flood waves in surface streams. U.S. Geological Survey Professional Paper 475-B, B192-B195. Washington, D.C.: U.S. Government Printing Office. 
Davidson, G.R., and R.L. Bassett. 1993. Application of boron isotopes for identifying contaminants such as fly ash leachate in groundwater. Environmental Science \& Technology 27, no. 1: 172-176.

Davis, K.R. 1996. The McNairy Formation in the area of the Paducah Gaseous Diffusion Plant, report KY/EM-148, prepared for the U.S. Department of Energy under subcontract to DOE contract DEAC05-76OR00001. Kevil, Kentucky: Martin Marietta Energy Systems.

Evaldi, R.D., and D.L. McClain. 1989. Stream flow, specific-conductance, and temperature data for Bayou and Little Bayou Creeks near Paducah, Kentucky, August 15 and 16, 1989. U.S. Geological Survey Open-File Report 89-582. Louisville, Kentucky: USGS.

Freeze, R.A., and J.A. Cherry. 1979. Groundwater. Englewood Cliffs, New Jersey: Prentice-Hall.

Hem, J.D. 1992. Study and interpretation of the chemical characteristics of natural water. U.S. Geological Survey Water-Supply Paper 2254, $3^{\text {rd }}$ ed. Washington, D.C.: U.S. Government Printing Office. Hendricks, S.P., and D.S. White. 1991. Physicochemical patterns within a hyporheic zone of a northern Michigan river, with comments on surface-water patterns. Canadian Journal of Fisheries and Aquatic Sciences 48: 1645-1654.

Hibbs, B.J. 1993. Numerical modeling and hydrologic analysis of floodplain hydrogeology, bank storage interactions, and underflow in the Colorado River alluvial aquifer. Ph.D. thesis, Department of Geological Sciences, The University of Texas at Austin.

Jacobs EM Team. 1998. Ground-water flow model recalibration and transport model construction at the Paducah Gaseous Diffusion Plant, Paducah, Kentucky, report DOE/OR/07-1742\&D0, prepared for the U.S. Department of Energy under subcontract to DOE contract DE-AC05-98OR22700. Kevil, Kentucky: Jacobs EM Team.

Job, C.A., and J.J. Simons. 1996. EPA update: Ground and surface water interaction, watershed management, and monitoring. Ground Water Monitoring and Remediation 16, no. 3: 68-69. 
Langston, C., J. McIntyre, and R. Street. 1998. Investigation of the shallow subsurface near the Paducah Gaseous Diffusion Plant using SH-wave seismic methods. Society of Exploration Geophysicists, 1998 Technical Program, Expanded Abstracts, Vol. 1, 878-880.

Larkin, R.G., and J.M. Sharp, Jr. 1992. On the relationship between river-basin geomorphology, aquifer hydraulics, and ground-water flow direction in alluvial aquifers. Geological Society of America Bulletin 104, no. 12: 1608-1620.

Lee, D.R. 1977. A device for measuring seepage flux in lakes and estuaries. Limnology and Oceanography 22, no. 1: 140-147.

Lorah, M.M., L.D. Olsen, B.L. Smith, M.A. Johnson, and W.B. Fleck. 1997. Natural attenuation of chlorinated volatile organic compounds in a freshwater tidal wetland, Aberdeen Proving Ground, Maryland. U.S. Geological Survey Water-Resources Investigations Report 97-4171. Baltimore, Maryland: USGS.

Lowrance, R. 1992. Groundwater nitrate and denitrification in a Coastal Plain riparian forest. Journal of Environmental Quality 21: 401-405.

Meyboom, P. 1961. Estimating groundwater recharge from stream hydrographs. Joumnal of Geophysical Research 66: 1203-1214.

Pearce, A.J. 1990. Streamflow generation processes, an austral view. Water Resources Research 26, no. 12: $3037-3047$.

Phillips, B.E., and J.W. Douthitt. 1993. Hydrogeologic assessment of the C-746-K landfill and vicinity, report KY/ER-24, prepared for the U.S. Department of Energy under subcontract to DOE contract DE-AC05-76OR00001. Kevil, Kentucky: Martin Marietta Energy Systems.

Plummer, L.N., E.C. Prestemon, and D.L. Parkhurst. 1994. An interactive code (NETPATH) for modeling net geochemical reactions along a flow path, version 2.0. U.S. Geological Survey WaterResources Investigations Report 94-4169. Reston, Virginia: USGS. 
Rantz, S.E., et al. 1982. Measurement and computation of streamflow, volume 1, Measurement of stage and discharge. U.S. Geological Survey Water-Supply Paper 2175. Washington, D.C.: U.S. Government Printing Office.

Rice, K.C., and G.M. Hornberger. 1998. Comparison of hydrochemical tracers to estimate source contributions to peak flow in a small, forested, headwater catchment. Water Resources Research 34, no. $7: 1755-1766$.

Roy, W.K., M.G. Ryon, R.L. Hinzman, J.G. Smith, J.J. Beauchamp, M.R. Smith, B.A. Carrico, R.P. Hoffmeister, M.K. McCracken, and R.A. Norman. 1996. Thermal discharges from Paducah Gaseous Diffusion Plant outfalls: impacts on stream temperatures and fauna of Little Bayou and Big Bayou Creeks, Oak Ridge National Laboratory Environmental Sciences Division report ORNL/TM-13183. Oak Ridge, Tennessee: Oak Ridge National Laboratory.

Silliman, S.E., and D.F. Booth. 1993. Analysis of time-series measurements of sediment temperature for identification of gaining vs. losing portions of Juday Creek, Indiana. Journal of Hydrology 146: $131-148$.

Simsiman, G.V., G. Chesters, and A.W. Andren. 1987. Effect of ash disposal ponds on groundwater quality at a coal-fired plant. Water Research 21, no. 4: 417-426.

Squillace, P.J. 1996. Observed and simulated movement of bank-storage water. Ground Water 34, no. 1: 121-134.

Squillace, P.J., E.M. Thurman, and E.T. Furlong. 1993. Groundwater as a nonpoint source of atrazine and deethylatrazine in a river during base flow conditions. Water Resources Research 29, no. 6: $1719-1729$.

Sturchio, N.C., J.L. Clausen, L.J. Heraty, L. Huang, B.D. Holt, and T.A. Abrajano, Jr. 1998. Chlorine isotope investigation of natural attenuation of trichloroethene in an aerobic aquifer. Environmental Science \& Technology 32, no. 20: 3037-3042. 
Thornthwaite, C.W., and J.R. Mather. 1957. Instructions and tables for computing potential evapotranspiration and the water balance. Publications in Climatology 10: 183-311.

Turner, J.V., and D.K. Macpherson. 1990. Mechanisms affecting streamflow and stream water quality: an approach via stable isotope, hydrogeochemical, and time series analysis. Water Resources Research 26, no. 12: 3005-3019.

U.S. Environmental Protection Agency. 1991. A review of methods for assessing nonpoint source contaminated ground-water discharge to surface water, report EPA/570/9-91-010. Washington, D.C.: USEPA.

Wallin, E.J. 1998. Ground-water/stream-water interactions in the vicinity of the Paducah Gaseous Diffusion Plant, McCracken County, Kentucky. M.S. thesis, Department of Geological Sciences, University of Kentucky.

Ward, C.H. 1996. Introductory talk: Where are we now? Moving to a risk-based approach. In Symposium on natural attenuation of chlorinated organics in ground water, U.S. Environmental Protection Agency report EPA/540/R-96/509, 1-3. Washington, D.C.: USEPA.

White, D.S. 1993. Perspectives on defining and delineating hyporheic zones. Journal of the North American Benthological Society 12, no. 1: 61-69.

White, D.S., C.H. Elzinga, and S.P. Hendricks. 1987. Temperature patterns within the hyporheic zone of a northern Michigan river. Journal of the North American Benthological Society 6, no. 2: 85-91.

Winter, T.C., J.W. Harvey, O.L. Franke, and W.M. Alley. 1998. Ground water and surface water, a single resource. U.S. Geological Survey Circular 1139. Denver, Colorado: USGS.

Wroblicky, G.J., M.E. Campana, H.M. Valett, and C.N. Dahm. 1998. Seasonal variation in surfacesubsurface water exchange and lateral hyporheic area of two stream-aquifer systems. Water Resources Research 34, no. 3: 317-328. 